\title{
Biodegradation of Wasted Bioplastics in Natural and Industrial Environments: A Review
}

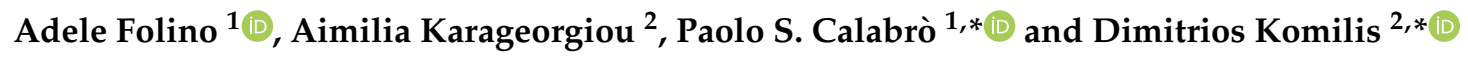 \\ 1 Dipartimento di Ingegneria Civile, dell'Energia, dell'Ambiente e dei Materiali, Università degli Studi \\ Mediterranea di Reggio Calabria, I-89122 Reggio Calabria, Italy; adelefolino@alice.it \\ 2 Department of Environmental Engineering, Democritus University of Thrace, 67132 Xanthi, Greece; \\ aimilia.karageorgiou@gmail.com \\ * Correspondence: paolo.calabro@unirc.it (P.S.C.); dkomilis@env.duth.gr (D.K.)
}

Received: 10 June 2020; Accepted: 24 July 2020; Published: 27 July 2020

\begin{abstract}
The problems linked to plastic wastes have led to the development of biodegradable plastics. More specifically, biodegradable bioplastics are the polymers that are mineralized into carbon dioxide, methane, water, inorganic compounds, or biomass through the enzymatic action of specific microorganisms. They could, therefore, be a suitable and environmentally friendly substitute to conventional petrochemical plastics. The physico-chemical structure of the biopolymers, the environmental conditions, as well as the microbial populations to which the bioplastics are exposed to are the most influential factors to biodegradation. This process can occur in both natural and industrial environments, in aerobic and anaerobic conditions, with the latter being the least researched. The examined aerobic environments include compost, soil, and some aquatic environments, whereas the anaerobic environments include anaerobic digestion plants and a few aquatic habitats. This review investigates both the extent and the biodegradation rates under different environments and explores the state-of-the-art knowledge of the environmental and biological factors involved in biodegradation. Moreover, the review demonstrates the need for more research on the long-term fate of bioplastics under natural and industrial (engineered) environments. However, bioplastics cannot be considered a panacea when dealing with the elimination of plastic pollution.
\end{abstract}

Keywords: bioplastics; bio-based; biodegradation; aerobic; anaerobic; aquatic; environment

\section{Introduction}

Plastics' low cost and their versatility have paved the way for a wide range of applications [1-6]. It is estimated that the annual production of conventional (petrochemical) plastic can exceed the amount of 350 million tonnes [7]. However, their extensive utilization has led to serious environmental pollution issues mainly due to the high amount of disposable plastic items, which is about $50 \%$ of the total mass of plastics generated [8]. From 1950 to 2015, less than $10 \%$ of the overall amount of plastic waste that was produced was actually recycled, while the remaining part was landfilled or released to the environment [9].

Due to the plastics' chemical and mechanical properties and particularly due to their durability, these polymers are posing a threat to the environment [10-12]. In particular, the production of the petroleum derived polymers increases the $\mathrm{CO}_{2}$ emissions in the atmosphere, thus contributing to the increase of greenhouse gases (GHG) $[6,13]$. Moreover, the ever-growing plastic waste that is accumulated into the landfills and in the marine environment $[3,14,15]$ has a huge impact on the living organisms of these ecosystems [16], in particular sea mammals and turtles that confuse plastic waste for food often leading to their suffocation after swallowing it. Microplastics-plastic particles characterized by a diameter less than $5 \mathrm{~mm}$ derived from macroplastics' degradation [17]—have 
been identified not only in food, drinking water, soil, and the air but also in the least expected areas, such as deep sediments around Antarctica and the ice of the Arctic [8]. Furthermore, microplastics, accounting for about 13\% of the plastic waste mass [18], and macroplastics may be mistaken for food by living organisms, which would be lethal as they would cause injuries $[11,19,20]$ or lead to detrimental effects on human health as a consequence of being ingested [21]. Apart from that, it is essential to reduce reliance on fossil fuels and to decrease the carbon footprint generated by the petroleum-based plastics [4]. In this paper, the terms "polymers" and "plastics" will be used interchangeably. It is clarified, however, that plastics are typically polymers in which plasticizers have been added.

The long-term existence of plastics in the environment $[2,5,11,16,20,22]$ as well as their resistance to degradation led to the development of new materials, the biodegradable bioplastics [23,24]. These materials may be decomposed by the same abiotic mechanisms that allow the disintegration of conventional plastics, such as photodegradation, oxidation, and hydrolysis [25] as well as by microbial degradation [8]. According to recent estimates [7], global bioplastics generation capacity slightly exceeds 2.1 million tonnes, which is equivalent to $0.6 \%$ of the global plastic generation.

The main objectives of this paper are to analyze the biodegradation of bioplastics and to investigate their ability to biodegrade under different conditions, namely under both aerobic and anaerobic environments. The process of biodegradation occurs in a bio-active environment under certain conditions such as in soil, marine and other aquatic environments, or during composting and anaerobic digestion [26-29]. Because the term bioplastics is prone to misunderstanding, the scope of this research focuses on the group of polymers that have the ability to biologically degrade; these are the biodegradable plastics, that can be of both natural (biogenic or biobased) and of fossil origin. In addition, since bioplastics are generally perceived as sustainable per definition, this review is intended to highlight the application potential of these materials so that to avoid their inappropriate and unsustainable use.

\section{Bioplastics}

Bioplastics were first manufactured back in the 1950s and re-emerged in the 1980s [29,30], but only recently received the necessary attention [31,32]; in particular, it was during the 2000s that their industrial-scale production began [33]. As per the survey carried out in this paper (Figure 1), we found that there is an increasing interest on bioplastics in the scientific literature (Journals covered by Scopus) with the rate of publications increasing dramatically in the last five years. The first scientific publication that was ever found on this topic was published in 1952 and was related to a medical application [34].

Bioplastics is a generic term that describes both bio-based plastics, namely the ones that are made of biogenic materials, and those plastics (including petrochemical ones) that are biodegradable; in fact, not all bio-based plastics are biodegradable. On the other hand, some biodegradable plastics may be of petrochemical origin [35-37]. Therefore, a bioplastic is the plastic that is either bio-based, biodegradable or both.

The bioplastics' annual production is relatively low, as it makes up less than one percent of the almost 360 million tonnes of plastics produced per year [7]. In 2019, their production was 2.11 million tonnes (of which $44.5 \%$ were bio-based/non-biodegradable bioplastics and $55.5 \%$ biodegradable bioplastics) [7]. Moreover, in 2024, the bioplastics' production is expected to reach about 2.43 million tonnes.

The growing interest on bioplastic research is shown in Figure 1. As evident, a lot of relevant publication were published in the period 2015-2020.

Bioplastics seem to be the ideal replacement for conventional plastics [22,38,39], since they can have similar applications. They are also a viable solution for environmental sustainability $[6,22,40]$ due to both their biodegradability [1,41-43] and the fact that biogenic raw materials are used to manufacture them (Table 1). Both those aspects contribute to the goals of circular economy. For instance, while bioplastics can be synthesized from chemicals produced by micro-organisms utilizing 
various waste products [44], the production of conventional plastics uses irreversible processes as they are fossil fuel based [45].

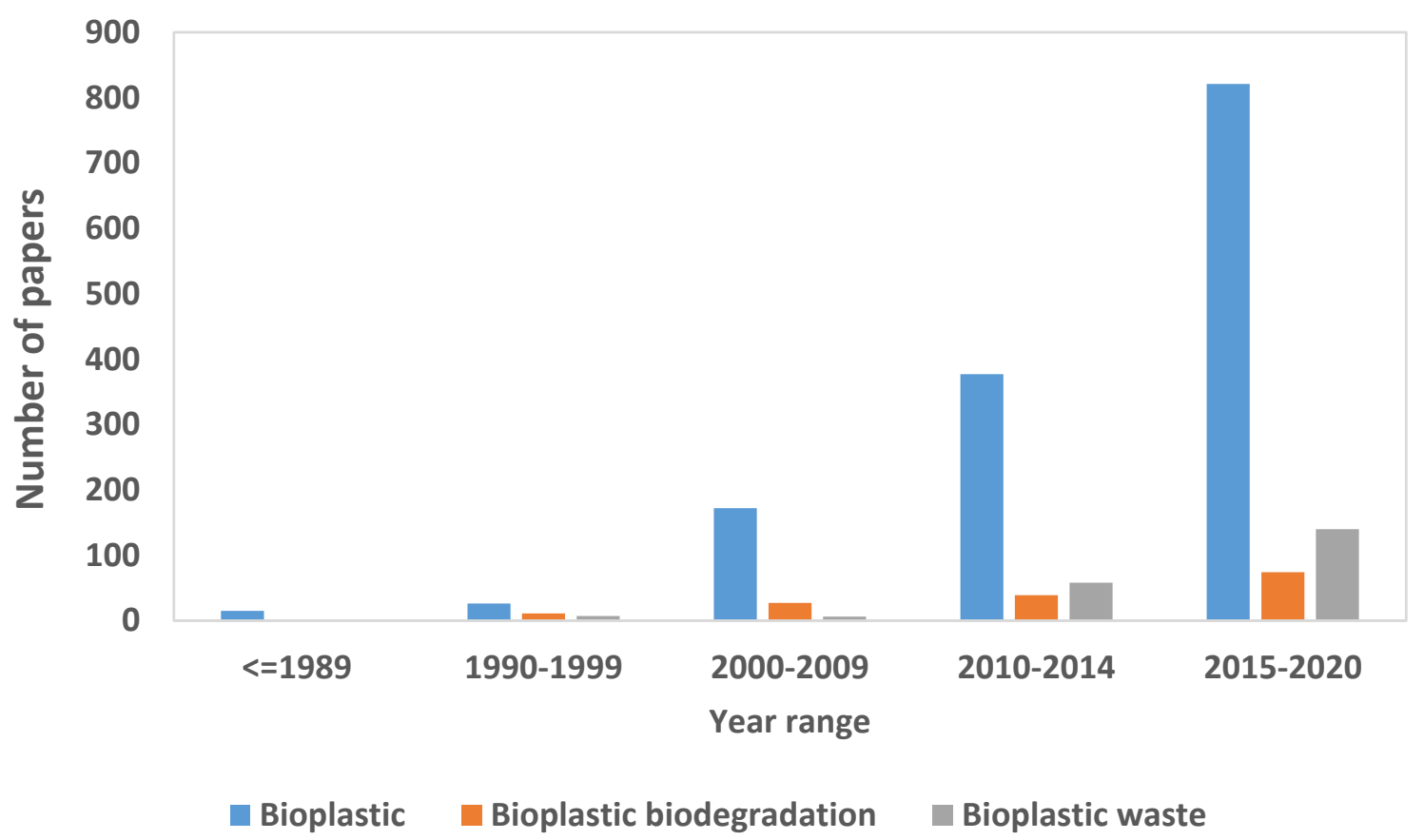

Figure 1. Documents registered in Scopus platform containing the specified terms in title, abstract, or keywords.

The possibility to produce bioplastics from waste is of extreme importance as replacing the production of conventional plastics with bio-based polymers would require about $0.02 \%$ of the total available Earth's arable land used for agricultural products [7]. This percentage is destined to increase by over $50 \%$ by 2050 for the estimated plastics' growth demand, leading to a serious question of whether land should be used for growing food crops, or as a tank for plastic, as had happened for first-generation biofuels that required significant land-based crops [8]. The majority of bioplastics is indeed still produced from agricultural crop-based feedstocks (carbohydrates and plant materials) [46] that both lead to increased water usage and to the reduction of food production [47]. Under this point of view, the adoption of new technologies to manufacture bioplastics will facilitate the transition from a fossil-fuel-based society, and an inefficient waste management, to one based on renewable resources, reduced fossil fuel consumption, and reuse-oriented waste management [48]. The latter situation agrees with the concept of circular economy.

\subsection{Classification of Bioplastics}

As already mentioned, the term bioplastics is used to describe plastics that can either be bio-based, or biodegradable, or they can feature both properties. Specifically, bio-based plastics are actually the polymers that have their carbon partially or wholly produced from renewable resources such as proteins and lipids [6,33,49-52], whereas biodegradable plastics are the polymers that are able to mineralize into carbon dioxide, methane, water, inorganic compounds, or biomass through the enzymatic action of specific microorganisms (bacteria, algae, and fungi) under the appropriate environmental conditions $[24,30,33,39,53]$. In addition, there are biodegradable plastics that are compostable only. Hence, these materials are capable of decomposition into carbon dioxide, water, inorganic compounds, and biomass via biological activities that take place in a compost system. Their decomposition rate is compared to other known compostable materials, such as cellulose, which is normally used as a control [33]. 
Table 1. Classification of plastics.

\begin{tabular}{|c|c|c|c|c|}
\hline Type & Biodegradability & Source & Example & References \\
\hline $\begin{array}{c}\text { Conventional } \\
\text { (petrochemical) plastics }\end{array}$ & Non-Biodegradable & Fossil Fuel Resources (petroleum, natural gas) & $\begin{array}{l}\text { PE, PS, PVC, PP, } \\
\text { PC, PU }\end{array}$ & {$[2,10,28]$} \\
\hline \multirow{3}{*}{ Bioplastics } & $\begin{array}{c}\text { Bio-based \& } \\
\text { Non-Biodegradable }\end{array}$ & Renewable Resources (corn, sugar cane, soybean) & $\begin{array}{l}\text { Bio-PE, Bio-PET, } \\
\text { Bio-PVC, Bio-PU }\end{array}$ & {$[28,55]$} \\
\hline & Biodegradable & Fossil Resources (petroleum, natural gas) & PBS, PCL, PBAT & {$[28,43]$} \\
\hline & $\begin{array}{l}\text { Bio-based \& } \\
\text { Biodegradable }\end{array}$ & Renewable Resources (corn, sugar cane) & PHA, PHB, PLA & {$[54,56]$} \\
\hline
\end{tabular}

The resources used to produce these polymers can be divided into two groups, the renewable resources (such as organics' waste biomass) and the fossil fuel resources. It is important to note that bioplastics can be classified into three categories (Table 1). The first category includes those that are bio-based and not biodegradable, the second those that are bio-based and biodegradable, and the third category, which includes those that are synthesized by petrochemical feedstock but are still biodegradable $[29,33,54]$.

This family of bioplastics is further subdivided into first-, second-, and third-generation bioplastics. First-generation bioplastics derive directly from renewable feedstock, which includes corn and sugar cane. Second-generation bioplastics come mainly from the monomers that are extracted by the first-generation's byproducts, such as peels and barks; the third-generation bioplastics are still being researched and their sources involve microorganisms, such as algae and modified microbial polymers $[27,53,57,58]$. The feasibility of PHA and PHB production by several bacterial strains (e.g., Ralstonia, Pseudomonas, Bacillus, and Vibrio [59]) has been demonstrated; engineered Escherichia coli produced PHB from starch [60], while the engineered Ralstonia eutropha (Re2133/pCB81) allowed the production of PHA copolymer PHBV [61] and terpolymer P(3HB-co-3HV-co-3HHx) [62].

Another subdivision of the bioplastic materials refers to the raw material they are made of (i.e., the type of polymers) and their ability to biodegrade. There exist bioplastics that are solely produced from one kind of feedstock, such as cellulose, but there are also others that are made of two or even three kinds of raw materials, the biocomposites. The bioplastics consisting of two raw materials are called co-polymers, while those that are produced by three different origins are the ter-polymers. Those blended-bioplastics maintain the features and abilities that each of their feedstocks provide [2,29]. Nonetheless, the most utilized bioplastics, with a percentage of $47 \%$ and $41 \%$ of the total use, are the PLA-based and the starch-based, respectively $[27,63]$. The most popular biopolymers in today's world are: PLA, PHA, TPS, Bio-PE, Bio-PET, cellulose polyesters, and starch-based bioplastics [2,64].

Other common biodegradable polymers produced by plants, animals, micro-organisms, or synthetically are PGA, PCL, PBS, PBAT, and PHB [25,45]. Among them, PLA is considered the most promising, as lactic acid can be obtained from corn and other crops $[8,25,65]$. For instance, fermentable sugars obtained from chemical treatment of food waste can be used as substrate by microorganisms to produce plastics precursors [44]. A feeding simulating fermented olive mill wastewater (OMWW) was used to extract PHA from mixed microbial cultures [66]. Other carbon sources used for synthesizing PHAs by microbes can include waste frying or cooking oil, coffee waste, crude glycerol, molasses, and wastewater [67-70]. Industrial and municipal wastewater sludge, agricultural, and food waste were used to produce PHB through SSF [71,72].

Another way to avoid the uncontrolled use of arable land for bioplastics would be the next-generation microalgae-based bioplastic production as they can be placed on non-arable land [46]. Moreover, microalgae captures $\mathrm{CO}_{2}$ by photosynthesis, reducing eutrophication of water bodies by using nutrient-rich wastewater [46].

Bioplastics can be synthesized from both biogenic and petrochemical feedstock [29]. They are produced by the fusion of biopolymers, plasticizers, fillers, and sometimes colorants [49]. Their production can be the result of chemical polymerization but also of biological or natural fermentation $[29,38]$. Chemical polymerization can occur regardless of the raw materials origin, as opposed to natural fermentation that can only take place by the utilization of renewable feedstocks. 
Therefore, the manufacture of bioplastics can be achieved through the following methods [4,29]:

- Chemical synthesis of finite fossil resources (e.g., petroleum);

- Chemical synthesis of biotechnologically manufactured polymer feedstocks;

- Direct biosynthesis of biogenic raw materials including organic waste;

- Production of blends and co-/terpolymers from the previously mentioned groups.

\subsection{Bioplastics' Utilization and Economical Aspects}

Even though the production of bioplastics is significantly lower than that of conventional plastics, a bioplastic material represents, in most cases, a suitable replacement for conventional plastics [23,33,52]. Therefore, the bioplastics have started to enter slowly into the market in a variety of sectors; the predominant ones are presented in Table 2 .

Table 2. Uses of bioplastics.

\begin{tabular}{|c|c|c|}
\hline Source of Bioplastic & Use & Ref. \\
\hline \multirow{3}{*}{ Cellulose-based } & Packaging & [5] \\
\hline & Sponge cloths & [73] \\
\hline & Electronics applications & [5] \\
\hline \multirow{6}{*}{ Starch-based } & Films & [74] \\
\hline & Rigid materials (such as plates and cutlery and foams) & {$[74,75]$} \\
\hline & Packaging & {$[30,75]$} \\
\hline & Medical products & {$[30,75]$} \\
\hline & Agriculture & {$[30,39,76]$} \\
\hline & Carrier bags & {$[16,77]$} \\
\hline \multirow{8}{*}{ PLA-based } & Packaging & {$[30,38,74,78]$} \\
\hline & Disposable or durable goods & [74] \\
\hline & Electronics applications & [38] \\
\hline & Fibres & [38] \\
\hline & Medical products & [30] \\
\hline & Building and construction & [78] \\
\hline & Agricultural field & {$[30,38]$} \\
\hline & Textiles and films & {$[64]$} \\
\hline \multirow{3}{*}{ PHA-based } & Medical products & {$[30,74,79-82]$} \\
\hline & Agriculture & {$[30,74]$} \\
\hline & Packaging & {$[30,82]$} \\
\hline \multirow{3}{*}{ Petroleum-based } & Medical products & [30] \\
\hline & Packaging & [30] \\
\hline & Agriculture & [39] \\
\hline
\end{tabular}

As shown in Table 2, bioplastics are used in a wide range of applications. This is attributed to the fact that several desired characteristics can be obtained (such as, flexibility, strength, shape memory capability, or resistance to liquids) by easily changing the processing conditions during their production. In general, packaging for both food and non-food materials is the most common use of bioplastics, independent of the type of their polymer-based source. 
Cellulose-based biopolymers are mainly used to produce engineering plastics and sheets for electronic applications as they can be used to obtain either shrink films and/or sheets or to drive shape memory effects [5].

PLA-based biopolymers show the widest range of applicability. Their mechanical properties depends on the crystalline structure of the PLA: Semicrystalline PLA is used in applications including rigid plastics $[64,78]$; on the other hand, the amorphous structure leads to a more flexible material (e.g., adhesives) [83].

PHA-based biopolymers are used in more niche applications, such as in medical and agricultural sectors [74]. Because of their biodegradability and nontoxic properties, applications of PHAs in the medical sector generally includes drug delivery systems, porous implants, support scaffolds for tissue engineering, and anti-microbial agents [84]. Their ability to act as drug delivery agents is affected by the different PHA monomer composition [80].

Starch-based biopolymers (especially thermoplastic starch) are mainly used for the production of rigid materials (such as plates and cutlery) [74] with high heat resistance [75]. Another important application includes the use of starch-based biopolymers as fungicides and/or insecticides in film-coatings applied to agronomic seeds to support seed germination against many diseases and early-season insect pests [76]. Also, PBS (a petroleum-based bioplastics) is a biopolymer often used as a binder for vegetables and fruit in agricultural fields [39].

Single-use bioplastics items such as bags, dishes, coffee stirrers, glasses, horticulture pots, mulching film, dust sheets, bottles, and packaging items are produced mainly by PLA, PHAs, starch, and cellulose pulp [85]. Bioplastics made from starch can be used for packaging apples and tomato slices with a high protective barrier [86]. PHAs are used in domestic, agricultural, industrial, and medical fields [82] because of their properties of water insolubility, ultraviolet resistance, and good barrier from oxygen penetration [87].

However, a variety of bioplastics is being nowadays industrially manufactured competing in price and performance with the oil-based polymers [27,33,54]. The energy requirement is lower for bioplastics (57 MJ kg-1) compared to conventional plastics (77 $\mathrm{MJ} \mathrm{kg}^{-1}$ ) [88], which impacts global warming less [44]; however, bioplastics still have higher production costs than conventional plastics. It is estimated that biopolymers' price is 2 to 5 times higher compared to the conventional plastics $[27,89]$ and ranges between $2-6 € \mathrm{~kg}^{-1}$ (depending on amount) as opposed to $1.2 € \mathrm{~kg}^{-1}$ for the latter ones $[29,33,90]$. However, there are kinds of biopolymers that are competitive with the fossil-derived polymers in terms of cost, namely the PLA and the thermoplastic-starch-based bioplastics [57]. On the other hand, most bioplastics are not yet cost-effective [27,85], due to the high cost of the manufacturing processes $[6,19,91]$. Nevertheless, $40 \%$ of the net cost of a commodity is linked to the carbon feedstock value [13]; therefore, the market potential for biopolymers heavily depends on the crude oil price [57]. Another issue limiting the bioplastic market may be the matching of the specific properties of a petroleum-derived plastic with those of the replacing 'biological' alternative [8].

\subsection{Properties of Bioplastics}

The biopolymers' capacity to make their way to the market is mainly due to their properties that are not at all inferior to those of the conventional petrochemical polymers $[6,53,54]$. Bioplastics are mostly known for their environmentally friendly nature due to their lower persistence when abandoned in the environment [16]. Through the utilization of renewable resources such as organic waste $[63,91]$, there exist additional benefits by the valorization of solid waste $[33,92]$ that would be otherwise landfilled or used for energy recovery [4]. Another property of the bioplastics is that they are non-toxic and compostable, which means that they are not harmful to living organisms [29,38,54].

A crucial point is that biopolymers should have similar mechanical $[33,54,93]$, chemical, and physical properties to conventional plastics $[54,93]$. These include tensile strength, tensile elongation, elasticity, flexural strength, density, crystallinity, melting point, water vapor and oxygen permeability, and also UV resistance $[12,13,38,93,94]$. 
However, the often low mechanical strength of bioplastics is the property that mostly limits their application $[95,96]$ and requires the use of synthetic fibers, such as glass or carbon, to increase this property [97]. This leads to environmental problems due to reduction of their biodegradability [97-100]. As a replacement of synthetic fibers, environmentally friendly materials, such as lignocellulosic fibers, fillers derived from cellulosic materials [101], starch [102], can be added to biopolymers to reinforce the produced bioplastic [97,103]. Nanomaterials, such as nanoclay [104] or chitosan [102], have been used to increase the thermal stability of bioplastics developed from starch [104], which are known to have poor mechanical properties, due to their intra- and intermolecular bonds [105]. Moreover, in a study conducted by Masruri and co-workers [106], the addition of essential oil from kaffir lime to starch from cassava peel waste to produce bioplastic was found to increase the stability in tensile strength and the plastic was able to elongate by $65-85 \%$. The simple addition of glycerol at a concentration of 5\% (w/w) produced a bioplastic with a higher tensile strength of $205.52 \mathrm{~N} \mathrm{~mm}^{-2}$ and $42.69 \%$ of elongation [86].

The addition of PLA (10\%) to starch-based bioplastics enhances the general properties of bioplastic composites [107]. PHAs have mechanical properties similar to synthetic plastics, are insoluble in water, and non-toxic, which makes them suitable for biomedical applications [69].

Another notable property of some bioplastics is the shape memory capability, which is a change of the shape of a material upon application of an external incentive [5]. Plasticizers, such as glycerol [86], glyoxal, or xanthan gum [108], are usually added to the starch-based bioplastics to improve their strength, flexibility [109], and the ability to process it [101]. An optimum bioplastics composition was found to be $12 \%(w / w)$ starch and $5 \%(w / w)$ glycerol [86].

However, when it comes to the disposal/waste management system, with very few exceptions [33,64], biopolymers cannot be chemically or mechanically recycled along with petrochemical plastics. For example, PLA can negatively impact the traditional recycling processes of PET $[77,110]$.

\subsection{Degradation of Bioplastics in the Environment}

Just like the rest of the products, bioplastics have a life cycle [33]. However, due to the wide variety of bioplastics, the life cycle of each material differs, depending on the type of bioplastic [19] and on the end-of-life scenarios according to the available waste management systems in each country [54]. The degradability of bio-polymers is affected by the chemical and physical structure of the materials $[4,29,111]$ and not by the origin of their resources or their production process $[4,29]$. As mentioned in Endres [29] "degradability is a functional property or a disposal option at the end of the material's life cycle". The degradation process depends on a combination of abiotic (UV, temperature, moisture, $\mathrm{pH}$ ) and biotic processes and parameters (microbial activity) [19,26,33,38,112].

It is worth mentioning that degradation differs from biodegradation. Degradation is a process of decomposition that stops at the fragmentation of polymers through the effect of heat, moisture, sunlight, and/or enzymes, which results in weakening the polymers' chains and thus creating even more persistent particles $[26,28,33,113]$; biodegradation is the complete mineralization of materials in compounds such as carbon dioxide $\left(\mathrm{CO}_{2}\right)$, water $\left(\mathrm{H}_{2} \mathrm{O}\right)$, ammonium $\left(\mathrm{NH}_{4}^{+}\right)$, nitrogen $\left(\mathrm{N}_{2}\right)$, hydrogen $\left(\mathrm{H}_{2}\right)$ and biomass through the biological action of microorganisms such as bacteria, algae and fungi $[5,24,54]$. Therefore, biodegradation is not detrimental for the natural environment since the compounds produced are naturally occurring in the ecosystem [24].

The residues from the bioplastics' biodegradation are not generally toxic [54] and can be consumed by other living organisms [26]. However, some issues have been mentioned in recent literature [77,114] linked to the presence of fossil resins in the bioplastic items composition. The process of biodegradation depends on factors such as humidity, temperature, oxygen content, $\mathrm{pH}$, time $[23,29,43]$, nutrient availability [19,23], UV radiation [28,94], and microorganisms' presence [23,29,115].

Another factor affecting the rate of biodegradation is the thickness of the biodegradable material: The thicker the product, the longer its biodegradability [28]. 
A key factor for biodegradation is the environment in which it takes place [5], and also the chemical composition, structure, and physical properties of the bioplastic material $[27,28,116]$. These are linked to the surface characteristics (hydrophobic or hydrophilic), the first-order structures (molecular weight, molecular weight distribution, chemical structure), and the higher-order structures (crystallinity, crystal structure, modulus of elasticity, glass transition temperature, melting temperature) of the polymers [116].

Biodegradable plastics can be subject to different biodegradation pathways; some of them (e.g., PHAs) can be directly biodegraded by microorganisms while the biodegradation of others is assisted and augmented by natural factors (e.g., UV, oxygen, heat). Oxidative-degradable polymers accelerate their decomposition under the effect of oxidation through heat and/or UV light $[23,28]$. UV radiation can disrupt polymer chains, since the radiation can be absorbed by oxygen-containing components to initiate a primary degradation; these polymers are known as photodegradable polymers. In other words, sunlight combined with oxygen can lead to photo-oxidative degradation, whereas sunlight combined with heat causes oxidative-degradation [29]. During photodegradation, both molar mass and crystal structure are affected [94]. The plastics characterized as hydro-biodegradable are those that have the capacity to biodegrade by hydrolytic mechanisms such as biopolymers made of cellulose, starch, and polyesters such as PHA.

The process of biodegradation of the bioplastics can be divided in three stages.

1. Firstly, the stage of bio-deterioration $[19,43,117,118]$, in which the polymers undergo chemical, mechanical, and physical change, as a result of the microorganisms' biological activity on the surface of the material $[19,43]$. The porosity highly influences this step.

2. The second stage is that of bio-fragmentation $[19,43,118]$, where the microbial activity causes the breaking down of polymers into oligomers and monomers [19,43].

3. The third stage describes the assimilation $[19,43,117,118]$ of bioplastics, in which the bio-fragmented compounds are used by the microorganisms and are converted to biodegradation end products, such as $\mathrm{CO}_{2}, \mathrm{H}_{2} \mathrm{O}$ and biomass $[19,43]$.

The decrease of mechanical properties occurs immediately at the bio-deterioration stage, while changes in surface features and mass loss occur together during bio-fragmentation and microbial assimilation [19].

To evaluate biodegradability, one must consider whether the term corresponds to the complete mineralization of a material by microbial metabolism or to a change in the chemical structure of the materials through microorganisms. The knowledge acquired for the process of biodegradation when referring to open and unmanageable ecosystems still has gaps, due to the wide range of physical and chemical conditions [19].

\subsection{Indices of Biodegradability}

The issue of standardization of biodegradability evaluation arose in the 1980s $[16,19,119]$. Biodegradability can be evaluated via:

- $\quad$ Monitoring of the bioplastics' weight reduction [3,10-12,19,22-24,32,51,54,63,77,92,120-124];

- $\quad$ The evolution of $\mathrm{CO}_{2}$ and/or $\mathrm{CH}_{4}[3,19,26,42,77,117,119]$;

- $\quad B O D$ (biological oxygen demand) measurements $[11,19,125]$ or the ratio BOD/ThOD (theoretical oxygen demand) [111];

- $\quad$ Surface morphology and the molecular weight of each material $[3,11,115,117,123,126]$.

However, it must be pointed out that the simple measurement of the weight loss of the tested materials, as adopted commonly in the literature, does not necessarily imply that the selected bioplastic has been mineralized. It is the measurement of $\mathrm{CO}_{2} / \mathrm{CH}_{4} /$ biogas production or of $\mathrm{O}_{2}$ consumption that indicates a microbial mineralization activity and should be elected as the optimal biodegradation indexes. 
Another way to quantify the biodegradability of a product is the decrease of TC (total carbon) [39]. There are also specific test methods that use the physical changes (e.g., discoloration, fragmentation) that the polymers undergo as indicators of biodegradability $[3,125]$. In addition, the biodegradability of oxo-degradable products (i.e. conventional plastics that practically fragment into micro-plastics but do not biodegrade at a molecular level) is assessed by ATP measurements [19]. Other biodegradability indicators make use of spectroscopy, to analyze the changes in the spectrum of bioplastics during the process, and of visual analysis [127].

The means that the assessment of biodegradability can differ depending on the conditions of the test system. For example, $\mathrm{BOD}_{5}$ is typically an indicator of aerobic biodegradation, while biogas generation is used to evaluate the biodegradability in anaerobic environments. However, biodegradation can be expressed under all circumstances (both aerobic and anaerobic conditions) by mass loss, surface erosion, reduction of molecular weight, the evolution of $\mathrm{CO}_{2}$, and the loss of mechanical properties $[19,22,125,127]$.

The process of biodegradation is influenced, apart from the material's physico-chemical structure, by the polymer's chain configuration. The longer the polymer's chain is, the more difficult it is to degrade. However, the polymer's crystallinity is also an important parameter of biodegradation, as the amorphous parts of the polymer are easier to degrade compared to the crystalline parts [111,126,128]. As stated in Massardier-Nageotte [111] "the more complex the formula, the less degradable because several micro-organisms are required to attack the different functions of the polymer".

It should be noted that other parameters affecting the biodegradability of a material are the conditions and properties of the test systems. These include volume and shape of the vessels, open or closed bottles, mixing or shaking modes, oxygen supply, and test duration. Water-soluble polymers are easier to degrade, as water is a key factor for the development of microorganisms [111].

\subsubsection{Anaerobic Biodegradation Indices}

When it comes to anaerobic conditions, according to Yagi et al. [122], the biodegradability is calculated as:

$$
\text { Biodegradability }(\%)=\frac{\sum V_{S}-\sum V_{B}+V_{I C}}{V_{M A X}} \cdot 100
$$

where:

$\sum V_{S}$ is the total $\mathrm{CO}_{2}$ and $\mathrm{CH}_{4}$ volume from the sample vessel under standard conditions in $\mathrm{L}$;

$\sum V_{B}$ is the total $\mathrm{CO}_{2}$ and $\mathrm{CH}_{4}$ volume from the blank vessel under standard conditions in $\mathrm{L}$;

$V_{I C}$ is the $\mathrm{CO}_{2}$ volume dissolved in the sludge in excess of the blank value under standard conditions in $\mathrm{L}$; $V_{M A X}$ is the maximum theoretical volume of the biogas $\left(\mathrm{CO}_{2}+\mathrm{CH}_{4}\right)$ evolved after complete biodegradation of the test material under standard conditions in $\mathrm{L}$.

Another volumetric method is reported in the ASTM D5526-94D norm that measures the percentage of conversion of organic carbon in the sample to carbon in gaseous form $\left(\mathrm{CH}_{4}\right.$ and $\left.\mathrm{CO}_{2}\right)$ [127]. Similarly, the evaluation of the specific methane yield of the test material by biochemical methane potential (BMP) tests can be used as a method to evaluate the anaerobic biodegradability of bioplastics [77,127].

In the following subsections, the main indices for the evaluation of aerobic and anaerobic biodegradability are reported, while a summary of standardizations and certifications rules for the definition of biodegradation in different environments is presented in Section 5.

\subsubsection{Aerobic Biodegradation Indices}

The rate of biodegradation under aerobic conditions is often measured in terms of the produced $\mathrm{CO}_{2}$ (as $\mathrm{mg} \mathrm{CO}_{2} \mathrm{~d}^{-1}$ ) or consumed $\mathrm{O}_{2}$ (as $\mathrm{mg} \mathrm{O}_{2} \mathrm{~d}^{-1}$ ). Referring to aerobic conditions during the composting process, the cumulative volume of $\mathrm{CO}_{2}$, compared with a blank and a positive material, is used as an index of microbial assimilation and organic fraction mineralization $[129,130]$. 
The fundamental chemical reaction is presented below [131]:

$$
\begin{aligned}
\text { Bioplastic }+\mathrm{O}_{2} & + \text { Nutrients } \rightarrow \\
& \rightarrow \mathrm{CO}_{2}+\mathrm{H}_{2} \mathrm{O}+\text { New Biomass }+ \text { Stabilized organic matter } \\
& +\mathrm{NH}_{3}+\text { sulfates }+\ldots+\text { Heat }
\end{aligned}
$$

Mass loss of samples extracted during the testing period is considered as an index of biodegradation [127]. It is well known that biodegradation is initiated from the outside surface to the inside of a material. For this reason, erosion and perforation increase the speed of degradation because the holes formed accelerate the diffusion of oxygen and enzymes into the biopolymers [23]. Mass loss is strongly dependent on the temperature of the process as at mild temperature conditions $\left(35-37^{\circ} \mathrm{C}\right)$ the percentage of biodegradation is about 2-times lower than that at higher temperatures (over $\left.55^{\circ} \mathrm{C}\right)[77,111,132]$. This effect is due to the efficient abiotic degradation at higher temperatures [77].

The degree of disintegration is generally measured following the standards ISO 14806 and ISO 20200 considering the percentage of particles, which are retained on a $2 \mathrm{~mm}$ sieve, after 90 days in a laboratory-scale test under aerobic conditions. The equation represents the loss of mass in the conditions set by the test:

$$
\text { Disintegration (\%) }=\frac{M_{i}-M_{f}}{M_{i}} \cdot 100
$$

where $M_{i}$ corresponds to the initial dry mass of bioplastics and $M_{f}$ represents the dry mass of the recovered bioplastic pieces after $2 \mathrm{~mm}$ sieving.

Visual or microscopic analysis is often used to confirm the results of other test methods $[77,132]$ and it is based on the signs of all visible degradation phenomena such as erosion or discoloration of the material [127].

\subsection{Bioplastic-Degrading Microorganisms}

Even though microorganisms are a key factor for bioplastics disintegration, their role during the biodegradation process is still poorly understood [38]. Biodegradation, through the microorganisms' action, enables carbon to be mineralized at the end of the biodegradable polymers' useful lives following their disposal, without releasing harmful compounds into the environment [133].

Typically, biodegradable polymers are decomposed by microbial attack in a single step [38]. The depolymerization releases monomers that are assimilated by the surrounding microorganisms [126]. Depolymerization occurs due to the functional process of intracellular and extracellular enzymes, with the latter consisting of endo- and exo-enzymes. Endo-enzymes are responsible for the random breaking of the internal bonds of the main polymer chain, whereas exo-enzymes break the polymer chain sequentially $[23,91]$.

Another basic mechanism in the biodegradation of biodegradable polymers via the action of microorganisms is the hydrolysis by enzymes, which improves the hydrophilicity of the material, resulting in lower molecular weight polymers, which facilitates microbial assimilation [118].

Differences in the biodegradation rates amongst biodegradable polymers are due to the structural and physicochemical properties of their surfaces, allowing stronger or weaker attack of microorganisms on the surface [116,134]. The process of biodegradation involves prokaryotic (bacteria, archaea) and eukaryotic (fungi and protozoa) microorganisms, which have the ability to degrade the polymeric matrix and/or utilize the energy-storing materials [28]. More than 90 types of microorganisms are responsible for biodegradation in different environments $[43,118]$. Bacteria and fungi are more commonly involved in bio-polymers' biodegradation $[38,115]$.

There are several bioplastics that present different biodegradation behaviors under aerobic and anaerobic conditions. One major reason, highlighting the importance of the microbial communities in biodegradation, is the influence of fungi. Fungi are only active in aerobic environment as well as in compost and soil. In other words, some polymers are mainly (or even only) degraded by fungi 
and not by bacteria, and will therefore biodegrade to a higher extent under aerobic conditions [28,52]. According to some studies, rates of biodegradation are slower under anaerobic conditions due to the lack of oxygen and due to the limited microbial diversity enzyme availability [118].

As already demonstrated, not every type of bioplastic can be degraded by every type of microorganism and vice versa. On the contrary, it is essential to take into consideration the fact that each material biodegrades better under specific conditions. For example, it has been reported that PCL can be degraded by bacteria isolates that exist in deep sea sediments, but these isolates are incapable of degrading other types of bioplastics, such as PLA, PHB, and PBS; however, there exist composting bacteria capable of degrading the latter [43]. An interesting detail is the fact that PCL-degrading microbes that have been located in deep seawater have not been found in coastal environments [20]. Another example would be that of PBS that under aerobic conditions (composting) presents an extent biodegradation of approximately $31 \%$ in 80 days, while PBS under anaerobic conditions (landfill) biodegrades only by $2 \%$ in 100 days [1]. This leads us to think that PBS's biodegradation is linked to the action of fungi that are absent under anaerobic conditions.

As displayed in Table 3, PLA is well degraded by actinobacteria that belong to the family Pseudonocardiaceae, and by other taxa that include members of the family Micromonosporaceae, Streptomycetaceae, Streptosporangiaceae, and Thermomonosporaceae [135]. PHAs and its copolymers can be degraded by several bacteria and fungi through production of intracellular and extracellular depolymerases [136]. In particular, Enterobacter sp. (four strains), Bacillus sp., and Gracilibacillus sp. were found to be the PHA-degrading strains in a tropical marine environment [134].

Table 3. Bioplastics-degrading microorganisms and conditions of degradation (adapted from Rujnić-Sokele and Pilipović, [28]).

\begin{tabular}{|c|c|c|c|c|}
\hline \multirow{2}{*}{$\begin{array}{c}\text { Microorganisms } \\
\text { Process }\end{array}$} & \multicolumn{2}{|c|}{ Anaerobic Bacteria and Archaea } & \multicolumn{2}{|c|}{ Aerobic Bacteria, Archaea and Fungi } \\
\hline & Thermophilic Digestion & Mesophilic Digestion & Industrial Composting & Home Composting \\
\hline Temperature Conditions & $50-60{ }^{\circ} \mathrm{C}$ & $\leq 35^{\circ} \mathrm{C}$ & $50-60^{\circ} \mathrm{C}$ & $\leq 35^{\circ} \mathrm{C}$ \\
\hline Chemical pulp & $\sqrt{ }$ & $\sqrt{ }$ & $\sqrt{ }$ & $\sqrt{ }$ \\
\hline Mechanical pulp & $x$ & $x$ & $\sqrt{ }$ & $\sqrt{ }$ \\
\hline Starch & $\sqrt{ }$ & $\sqrt{ }$ & $\sqrt{ }$ & $\sqrt{ }$ \\
\hline Starch/PCL & $x$ & $\sqrt{ }$ & $\sqrt{ }$ & $\sqrt{ }$ \\
\hline PLA & $\sqrt{ }$ & $x$ & $\sqrt{ }$ & $x$ \\
\hline PHA & $\sqrt{ }$ & $\sqrt{ }$ & $\sqrt{ }$ & $\sqrt{ }$ \\
\hline PBAT & $x$ & $x$ & $\sqrt{ }$ & $\sqrt{ }$ \\
\hline
\end{tabular}

As a result, it is indicated that each biopolymer requires unique handling and disposal management. There is a need for further investigation to understand the effects of microorganism species, population, and enzyme specificity depending on the different microbial environments on the biodegradation process [35].

\section{Waste Management Options for Bioplastics}

Bioplastics is a large family of polymers that include many different materials. Each should be treated by a different waste management option according to its characteristics [52]. Fossil-based polymers have been only minimally replaced by bioplastics and the impact of these new materials on waste accumulation is still not completely evaluated [82]. Although petroleum- and bio-based plastics may have similar mechanical properties, they are produced from different raw materials, thus the introduction of bioplastics in treatment/recycling systems used for traditional plastics is not feasible. In this sense, the redesign of current recycling systems is needed to further limit the potential environmental impact of bioplastics $[16,82]$ and to avoid an excessive resource use. On the other hand, products like PLA can be processed by several waste recovery methods, such as mechanical recycling and chemical recycling [36]. 
The options for the management of bioplastics at the end of their life are mainly dependent on the physico-chemical conditions of the treatment, and include: Biological waste treatment, recycling, incineration, and landfilling $[28,33,64]$. The process of biodegradation occurs during the biological waste treatment (e.g., composting, anaerobic digestion) and it can take place in a variety of environments $[33,121]$. For instance, bioplastics can be degraded in aerobic environments such as in soil, composting, and some aquatic environments, but also in anaerobic environments such as anaerobic digestion plants, landfills, and a few aquatic environments [28].

\subsection{Mechanical and Chemical Recycling}

According to EPA, only $9 \%$ of the annually manufactured plastic enters the waste stream for recycling [64]. However, bioplastics can be mechanically recycled.

Mechanical recycling of biopolymers was introduced in the 1970s and consists of the mechanical processing of plastics' waste to obtain secondary raw material for the production of new objects with similar properties. Mechanical recycling consists of the following phases [82,137,138]:

- Removal of contaminants, such as food waste [36];

- Grinding/shredding/crushing or milling, to obtain a material as much homogeneous as possible.

- Further processing, such as extrusion, injection molding, or drawing.

The main disadvantage of this scenario is the fact that normally each polymer should be separately treated to obtain a good secondary raw material and that every time a biopolymer is reprocessed there is loss in the physical and mechanical properties of the material [139]. For instance, even though very few studies on pure PHA recycling are available [82], PHA can be recycled but it exhibits a loss in mechanical properties [140]. Similar findings are observed in terms of reduction of tensile strength for PHB after multiple processing cycles, even though its chemical structure and thermal stability remains unchanged [140]. Other biocomposites, such as PHBV (a copolymer of PHB and PHV), have the ability to be recycled up to five times without experiencing any physico-mechanical losses [30].

Apart from that, when a biopolymer enters into the recycling stream with the rest of the conventional plastics, it might cause contamination to the waste as not all of the bioplastics are compatible for recycling, resulting in the potential downgrade in the quality and physical integrity of the producing mixed-plastic products $[30,53,139]$. To limit the contamination of waste and the subsequent problems for recycling, the different plastics should be sorted out by consumers. However, it can be difficult to distinguish between bioplastics and conventional plastics [36]. Nonetheless, mechanical recycling as recovery option is a costly and energy-intensive process [139], mainly due to the cost needed for separation of collected bioplastics, such as those from municipal solid waste [82].

In case of heterogeneous plastics' wastes, chemical treatment (depolymerization and refining) can be a better recycling option [141] to recover alternative fuels and chemicals as replacements to the fossil ones, thus reducing the need of virgin chemicals [30]. PET is suitable for both mechanical and chemical recycling [36] as it can be efficiently depolymerized into its monomers.

Currently, chemical recycling and energy recovery via thermal treatment should be preferred due to the difficulties of post collection sorting [36].

\subsection{Biological Treatment}

Biodegradability evaluation is crucial when bioplastics are biologically treated [26]. As demonstrated by Scott [139] "polymers must remain stable during manufacture and use but should break down rapidly after disposal with conversion to biomass and/or mineralization in an acceptable time". This summarizes the main idea that pushed to develop the bioplastics. Among the other treatment methods for used bioplastics, microbial degrading activity is a useful way for increasing environmental safety and economic value [135].

Biological treatment applies strictly on biodegradable bioplastics, due to the fact that this disposal option utilizes the feature of biodegradability that these polymers provide. The benefit resulting 
from these treatments, apart from reducing the amount of waste that would otherwise be dumped in the landfills, is energy recovery via anaerobic digestion and/or production of a soil amendment via composting [33]. Since the aim of this study is to summarize and compare the biodegradability of bioplastics by the action of microorganisms, biological treatments (such as composting or anaerobic digestion) as well as biodegradation of bioplastics in other environments (such as soil and aquatic environment) are further explained in Section 4 "Biodegradation under different environments".

\subsection{Incineration}

Incineration, which is a frequent waste management option, is the thermochemical decomposition of a substance by heating, where the organic materials are burnt for energy recovery. Its main benefit is that it can be applied to all types of polymers and the produced energy from polymers' incineration can be profitable if sold [139]. Another noteworthy ability, apart from the same calorific value, that bio-based bioplastics have over the conventional plastics is that they are $\mathrm{CO}_{2}$-neutral. On the contrary, the fossil-derived biodegradable bioplastics, contribute to the rise of GHG emissions as their feedstock is of fossil origin. The differentiation between biogenic and fossil carbon lies in the fact that the latter was fixed by primary producers from the atmosphere millions of years ago, and then sequestered, becoming unavailable to global bio-geo-chemical cycles. However, its sudden and massive recent release into the atmosphere following combustion processes, in the form of fossil-derived $\mathrm{CO}_{2}$, is believed to cause global warming [54].

Moreover, although recycling and materials recovery should be preferred over other waste disposal options, incineration represents a viable alternative to landfill disposal for many countries [36] as it is a means to recover energy.

\subsection{Landfilling}

It is estimated that almost $40 \%$ of the annually produced plastics is discarded into sanitary landfills [14,42]. Landfilling is still a popular waste management scenario, due to its low cost and simplicity of operation, as previous sorting of waste, or any other pretreatment, is not required. Nonetheless, disposal of bioplastic waste to a sanitary landfill remains the least preferable option (but preferred over the uncontrolled dumping). That is mainly because under anaerobic conditions, such as in landfill or dumps, anaerobic decomposition results in fugitive methane, which is a greenhouse gas when escaping the recovery system [64]. In fact, these generated greenhouse gases include methane $\left(\mathrm{CH}_{4}\right)$, which is a gas with a warming potential 25-36 times that of $\mathrm{CO}_{2}$ [54]. However, the landfill gas can be at least partially recovered and combusted for energy production [28,64].

\section{Biodegradation under Different Environments}

The ability to biodegrade under conditions existing in natural environments is a valuable property of bioplastics [142]. One of the key aspects for their development is in the possibility of avoiding plastic waste accumulation in the environment and, especially, in the oceans. As already demonstrated, biodegradability depends on the chosen environment and it can differ from one environment to another [38]. So, the environmental conditions affect the rate of decomposition [29,112], as well as the test conditions used [111], and the type of the biodegradable polymer that is being examined [112] should be chosen properly. Most commonly examined degradation environments were aerobic, such as those of compost [127], which is a common waste treatment option.

Other environments of interest are soil, fresh, or marine water [143]. However, the degradation of bioplastics happens only under certain conditions and often, in ambient conditions, the process of biodegradation is very slow [143]. For example, temperature is lower than the melting point and the glass transition $\left(55-62{ }^{\circ} \mathrm{C}\right)$ of thermoplastic polymers over which structural changes take place facilitating microbial growth and enzymatic activity [143,144]. 


\subsection{Aerobic Biodegradation of Bioplastics}

Under aerobic conditions, the process of biopolymers' biodegradation is an environmentally friendly approach accounting for an accelerated decomposition of heterogeneous organic waste via the enzymatic action of a high in diversity microbial population in a moist and warm environment under controlled conditions.

Soil and composting are common environments for the aerobic biodegradation of bioplastics. In general, PLA and PCL better degrade in compost compared to soil and liquid environment as the process conditions ( $\mathrm{pH}$, temperature, humidity) are optimal during controlled composting [145]. This is also confirmed in a study conducted by Cho et al. [1] due to the fact that under aerobic conditions (composting), the PCL-starch blend showed a rate of biodegradation of approximately $88 \%$ in 44 days, whereas under anaerobic conditions (buried in a landfill), the exact same material reached a biodegradation rate of $83 \%$ in 139 days.

\subsubsection{Biodegradation of Bioplastics in Soil}

The rate of biodegradation is influenced by the type of the selected soil environment. Depending on the microorganisms' population as well as the $\mathrm{pH}$ of the investigated area, biodegradability can differ $[43,117,123]$. Since several kinds of soil environments, with different characteristics, are present in nature, microbial biodegradation process can change from place to place and season to season [145]. For instance, degradability of PLA and PCL in alkaline conditions is higher than in neutral and acidic conditions [146].

Even though material properties account for most of the differences in the biodegradation rates, soil characteristics may also be the cause $[117,120]$. Biodegradation of bioplastics can be undertaken by several bacteria found in the soil such as Pseudomonas sp., Streptococcus sp., Staphylococcus sp., Bacillus sp., and Moraxella sp. Since water is the medium of most microorganisms present in soil, the absorption of water from the soil initiates the hydrolysis reaction [23]. A soil humidity of $50-60 \%$ is optimal for aerobic biological processes [145,147].

When soil-biodegradation of bioplastic has passed, test methods are used to evaluate its impact on the soil. These tests apply seed germination indexes where a value $\geq 95 \%$ indicates the absence of a toxic effect to seeds [117].

It has been observed that the sudden addition of high amounts of biodegradable materials causes a disturbance to the soil environment. If any fresh organic matter, regardless of whether it is bioplastic or not, is added in high quantities in soil, it is expected to cause transient "toxic" effects. During the biodegradation process of some natural substances (i.e., polysaccharides), phyto-toxicity may be caused since the biodegradation phase can deplete soil oxygen and produce metabolic intermediates. This may cause a short-term disturbance and unfavorable conditions to the soil-microorganisms and plants [126]. This must be taken into account when biodegradable polymers are directly and purposely added into the soil, such as the materials used in agriculture (as for example for mulch, irrigation tubes, pots, etc.) [145] or throughout digestate or compost containing partially degraded bioplastics [16]. In this case, the degradation time must be compatible with the crop or the application cycle, otherwise a plastic littering problem may occur [145].

A summary of the main studies carried out on bioplastics' biodegradation in soil environment is included in Table 4. The table shows the degree of biodegradation for bio- and petroleum-based bioplastics under the specified environmental conditions and the time required to achieve that biodegradability.

In a biodegradation test carried out on starch-based bioplastics, an increase of degradation with increasing starch dosage was observed and a degradation of about $95 \%$ was found [102]. The biodegradation was accelerated by the presence of water that led to faster break down and allowed further attack of microorganisms.

Starch-based plastic films, buried in field soil, were found to lose weight and degrade faster (one week) compared to PLA, PBSA, and PHAs, while PLA maintained its weight for the longest period (about 12 weeks) [36]. Another study, carried out under controlled condition on PLA/PHA nonwoven mulches, found that a mass loss of $90 \%$ was achieved after 180 days at temperatures $>60{ }^{\circ} \mathrm{C}$ and occasional UV irradiation and water spraying [148]. 
Table 4. Studies carried out on bioplastics' degradation in soil environment (adapted from Emadian et al. [43]).

\begin{tabular}{|c|c|c|c|c|c|c|c|c|c|}
\hline $\begin{array}{l}\text { Source of } \\
\text { Bioplastic }\end{array}$ & & Name of Bioplastic & Type of Environment & Conditions & Scale & $\begin{array}{l}\text { Biodegradation } \\
\text { Indicator }\end{array}$ & Biodegradability (\%) & $\begin{array}{c}\text { Period of } \\
\text { Biodegradability } \\
\text { (Days) }\end{array}$ & Ref. \\
\hline \multirow{29}{*}{ Bio-based } & \multirow{5}{*}{ PLA-based } & PLA & Soil & $30 \%$ moisture & $\begin{array}{l}\text { Buried at a depth of } 12-15 \mathrm{~cm} \text { in boxes of } \\
\text { alluvial-type soil }\end{array}$ & Weight loss & 10 & 98 & [32] \\
\hline & & PLA (powdered) & Soil & $25^{\circ} \mathrm{C}, 60 \%$ humidity & 50 g-soil/pot & Weight loss & 13.8 & 28 & [39] \\
\hline & & PLA/NPK fertilizer (63.5/37.5\%) & Soil & $30^{\circ} \mathrm{C}, 80 \%$ humidity & $\begin{array}{l}\text { Buried in the topsoil located outside } \\
\text { natural environment }\end{array}$ & Weight loss & 37.4 & 56 & [12] \\
\hline & & $\begin{array}{l}\text { PLA/NPK fertilizer/EFB } \\
(25 / 37.5 / 37.5 \%)\end{array}$ & Soil & $30^{\circ} \mathrm{C}, 80 \%$ humidity & Buried in the topsoil; likely in the lab & Weight loss & 43 & 56 & [12] \\
\hline & & PLA/sisal fiber (SF) (60/40\%) & Soil & $30 \%$ moisture & $\begin{array}{l}\text { Buried at a depth of } 12-15 \mathrm{~cm} \text { in boxes of } \\
\text { alluvial-type soil }\end{array}$ & Weight loss & $>60$ & 98 & [32] \\
\hline & \multirow{15}{*}{ PHA-based } & PHB & Soil & - & Lab-scale container & Weight loss & 64.3 & 180 & [91] \\
\hline & & PHB & Microbial culture from soil & Aerobic & $3 \mathrm{~L}$ sealable, sterile container & Weight loss & $\sim 18$ & 18 & {$[128]$} \\
\hline & & PHA & Soil & $35 \%$ moisture & $\begin{array}{l}\text { Buried at a depth of } 12-15 \mathrm{~cm} \text { in boxes of } \\
\text { alluvial-type soil }\end{array}$ & Weight loss & 35 & 60 & [124] \\
\hline & & PHA & Soil/compost $(90 / 10 \%)$ & $25^{\circ} \mathrm{C}, 65 \%$ humidity & $\begin{array}{l}\text { Lab-scale desiccator } \\
\end{array}$ & Produced $\mathrm{CO}_{2}$ & $40-50$ & 15 & [117] \\
\hline & & PHA & Soil & $20^{\circ} \mathrm{C}, 60 \%$ moisture & $2 \mathrm{~L}$ wide mouth jar & Produced $\mathrm{CO}_{2}$ & 48.5 & 280 & [54] \\
\hline & & PHBV & Microbial culture from soil & - & $3 \mathrm{~L}$ sealable, sterile container & Weight loss & $\sim 41$ & 18 & [128] \\
\hline & & PHB films & Soil (Hoa Lac, Vietman) & Natural conditions $-15 \mathrm{~cm}$ depth & Close-meshed gauze jackets & Weight loss & 98 & $\sim 365$ & [123] \\
\hline & & PHBV films & Soil (Hoa Lac, Vietman) & Natural conditions $-15 \mathrm{~cm}$ depth & Close-meshed gauze jackets & Weight loss & 61 & $\sim 365$ & [123] \\
\hline & & PHB pellets & Soil (Hoa Lac, Vietman) & Natural conditions $-15 \mathrm{~cm}$ depth & Close-meshed gauze jackets & Weight loss & 55 & $\sim 365$ & [123] \\
\hline & & PHBV pellets & Soil (Hoa Lac, Vietman) & Natural conditions $-15 \mathrm{~cm}$ depth & Close-meshed gauze jackets & Weight loss & 35 & $\sim 365$ & {$[123]$} \\
\hline & & PHB films & Soil (Dam Bai, Vietman) & Natural conditions $-15 \mathrm{~cm}$ depth & Close-meshed gauze jackets & Weight loss & 47 & $\sim 365$ & [123] \\
\hline & & PHBV films & Soil (Dam Bai, Vietman) & Natural conditions $-15 \mathrm{~cm}$ depth & Close-meshed gauze jackets & Weight loss & 14 & $\sim 365$ & {$[123]$} \\
\hline & & PHB pellets & Soil (Dam Bai, Vietman) & Natural conditions $-15 \mathrm{~cm}$ depth & Close-meshed gauze jackets & Weight loss & 28 & $\sim 365$ & [123] \\
\hline & & PHBV pellets & Soil (Dam Bai, Vietman) & Natural conditions $-15 \mathrm{~cm}$ depth & Close-meshed gauze jackets & Weight loss & 8 & $\sim 365$ & [123] \\
\hline & & PHA/Rice Husk (RH) (60/40\%) & Soil & $35 \%$ moisture & $\begin{array}{l}\text { Buried at a depth of } 12-15 \mathrm{~cm} \text { in boxes of } \\
\text { alluvial-type soil }\end{array}$ & Weight loss & $>90$ & 60 & [124] \\
\hline & \multirow{6}{*}{ Starch-based } & Starch-based & Soil & $20{ }^{\circ} \mathrm{C}, 60 \%$ moisture & $2 \mathrm{~L}$ wide mouth jar & Produced $\mathrm{CO}_{2}$ & 14.2 & 110 & [54] \\
\hline & & Mater-Bi plastic carrier bags & Soil & $25^{\circ} \mathrm{C}$ & Lab-scale cylinder $(30-20 \mathrm{~cm})$ & Weight loss & 37 & 90 & [22] \\
\hline & & Mater-Bi plastic carrier bags & Soil & Uncontrolled & Real filed $-5 \mathrm{~cm}$ depth & Weight loss & 3.4 & 90 & [22] \\
\hline & & Starch/chitosan (35/65) & Soil & Stockpiled sample on the ground & $\begin{array}{l}\text { n.a. } \\
\end{array}$ & Weight loss & 80 & 14 & [149] \\
\hline & & Starch/chitosan (35/65) & Soil & Soil burial test method & Lab-scale & Weight loss & 96 & 28 & [102] \\
\hline & & Cassava starch/glycerol (3/1) & Compost soil & $\begin{array}{l}\text { Soil Burial Test,. room } \\
\text { temperature }\end{array}$ & Lab-scale & Weight loss & 30 & 10 & [150] \\
\hline & \multirow{3}{*}{ Cellulose-based } & Rice straw bioplastics & Soil & Undefined & Lab-scale & Weight loss & $\approx 100$ & 103 & [5] \\
\hline & & Sponge cloth (cellulose-based) & $\begin{array}{c}\text { Synthetic soil } \\
\text { containing compost }\end{array}$ & Aerobic, $58^{\circ} \mathrm{C}$ & $\begin{array}{l}\text { Laboratory-scale controlled } \\
\text { composting conditions }\end{array}$ & Weight loss & $>80$ & 154 & [73] \\
\hline & & $\mathrm{Nylon}_{4}$ (Polyamides, Bio-based) & Composted soil & $\begin{array}{l}25^{\circ} \mathrm{C}, \mathrm{pH}=7.5-7.6, \\
80 \% \text { humidity }\end{array}$ & Buried in containers made of $\mathrm{PP}$ & Weight loss & 100 & 120 & [133] \\
\hline
\end{tabular}


Table 4. Cont.

\begin{tabular}{|c|c|c|c|c|c|c|c|c|c|}
\hline $\begin{array}{l}\text { Source of } \\
\text { Bioplastic }\end{array}$ & & Name of Bioplastic & Type of Environment & Conditions & Scale & $\begin{array}{l}\text { Biodegradation } \\
\text { Indicator }\end{array}$ & Biodegradability (\%) & $\begin{array}{c}\text { Period of } \\
\text { Biodegradability } \\
\text { (Days) }\end{array}$ & Ref. \\
\hline \multirow{9}{*}{ Petroleum-based } & \multirow{4}{*}{ PBS-based } & PBS (films) & Soil & $25^{\circ} \mathrm{C}, 60 \%$ humidity & $100 \mathrm{~g}$-soil/pot & Weight loss & 1.2 & 28 & [39] \\
\hline & & PBS (powdered) & Soil & $25^{\circ} \mathrm{C}, 60 \%$ humidity & $50 \mathrm{~g}$-soil/pot & Weight loss & 16.8 & 28 & [39] \\
\hline & & PBS/starch (films) (50/50\%) & Soil & $25^{\circ} \mathrm{C}, 60 \%$ humidity & $100 \mathrm{~g}$-soil/pot & Weight loss & 7.2 & 28 & [39] \\
\hline & & PBS/starch (powdered) (50/50\%) & Soil & $25^{\circ} \mathrm{C}, 60 \%$ humidity & $50 \mathrm{~g}$-soil/pot & Weight loss & 24.4 & 28 & [39] \\
\hline & \multirow{5}{*}{ PCL-based } & PCL & Soil & $28^{\circ} \mathrm{C}, 60 \%$ humidity & Lab-scale & Weight loss & 90 & 60 & [151] \\
\hline & & PCL & Soil and leachate & $28{ }^{\circ} \mathrm{C}, 60 \%$ humidity & Lab-scale & Weight loss & 22 & 60 & [151] \\
\hline & & PCL & Alluvial-type soil & $\begin{array}{c}\text { Samples buried at } 15 \mathrm{~cm} \text { depth, } \\
60 \% \text { humidity }\end{array}$ & Lab-scale & Weight loss & $<5$ & 48 & [152] \\
\hline & & PCL/chitosan (80/20) & Alluvial-type soil & $\begin{array}{c}\text { Samples buried at } 15 \mathrm{~cm} \text { depth, } \\
60 \% \text { humidity }\end{array}$ & Lab-scale & Weight loss & 20 & 48 & [152] \\
\hline & & PCL/starch (75/25) & Soil & $20^{\circ} \mathrm{C}, 40 \%$ humidity & Plastic bottles & Weight loss & 37 & 270 & [153] \\
\hline
\end{tabular}


Cellulose-based bioplastics showed the highest biodegradability (from 80 to 100\%) in a period over 100 days $[5,73,133]$.

From Table 4, it is observed that most studies to investigate bioplastics' biodegradation are based on weight loss. This can be a misleading indicator to assess biological mineralization, which is the desired final process in a complete biodegradation process.

\subsubsection{Biodegradation of Bioplastics in Compost}

The vast majority of biodegradable polymers are compostable (e.g., PLA, TPS), which is one of the reasons that the composting process is one of the most preferable options when it comes to the bioplastics' disposal [3,28,43,112]. Composting is an effective means for the solid waste valorization [1,92]; it has the ability to turn a heterogeneous fraction, such as organic waste combined with biodegradable-compostable plastic waste, into a homogeneous useful material $[33,38,51,154]$. Moreover, the $\mathrm{CO}_{2}$ produced does not contribute to the rise of GHGs in the atmosphere, as it is already part of the elemental cycles, and specifically the biological carbon cycle $[26,33,54,73]$. Compost, the main product of composting, is an organic-rich, biological material dominated by the so-called humic compounds, which is a rather stable form of organic matter. Specifically, compost is of unique physical and nutritional structure, which explains its high microbial diversity [27,33,38], and is a valuable product used in soil amendment [33,35,38,154].

The equation best describing composting is the following:

$$
\mathrm{C}_{a} \mathrm{H}_{b} \mathrm{O}_{c} \mathrm{~N}_{d}+e \mathrm{O}_{2} \rightarrow n \mathrm{C}_{w} \mathrm{H}_{x} \mathrm{O}_{y} \mathrm{~N}_{z}+s \mathrm{CO}_{2}+r \mathrm{H}_{2} \mathrm{O}+(d-n z) \cdot \mathrm{NH}_{3}
$$

where:

$$
\begin{gathered}
s=a-n w \\
r=\frac{b-n x-3 \cdot(d-n z)}{2} \\
e=\frac{n y+2 s+r-c}{2}
\end{gathered}
$$

Biological decomposition is faster in a composting plant with continuous aeration and moisture control $[38,155]$. Industrial composting facilities provide the appropriate conditions for microorganisms growth, such as control of moisture (between 50-60\%), oxygen concentration (over 5\%), C/N ratio (in the range 20:1-40:1) and temperature (up to $60^{\circ} \mathrm{C}$ ) $[4,15,26,54,92]$.

The composting process of bioplastics can be realized at both the industrial scale and at a domestic scale. Even though there are some differences, the procedure and the resulting products are equivalent. In particular, the home composting temperatures are usually lower than those occurring at industrial level. Moreover, complete biological biodegradability of a material does not necessarily mean it is also compostable [29]. In addition, a compostable product is always biodegradable, but a biodegradable product does not have to be compostable [43]. These differences are better explained in the paragraph "4. Standardization and Certification of Bioplastics".

According to the EN 13432 norm and the ASTM standards, among all the important requirements for a bioplastic to be considered as compostable, the most relevant ones refer to index of biodegradation $[16,28,33,38]$. In particular, at least $90 \%$ of the weight of the bioplastic should be degraded within six months in a controlled composting environment. In addition, a disintegration of at least $90 \%$ of the mass to fragments less than $2 \mathrm{~mm}$ should occur, when in contact with organic materials for a period of three months. However, recent studies (Table 5) outlined how composting of bioplastics can be problematic [16,156]. For instance, the existing plants processing bioplastics materials (such as composting plants, plastic sorting and recycling facilities, incineration, mechanical-biological treatment plants) may be not effective in the management of bioplastics since they were not designed to process these materials [16]. As a consequence, improvements in existing plants to process mixtures containing bioplastics and other organic materials should be identified and implemented [16]. As shown in Table 5, petroleum-based bioplastics show high degradability (over 90\% in less than three months $[1,35])$ in composting environments. Bio-based bioplastics also showed a high degree of biodegradability. For instance, PHB showed up to $80 \%$ of biodegradation in less than four months $[157,158]$, and cellulose-based bioplastics showed complete degradation after a period of three to five months [51,133]. 
Table 5. Studies carried out in simulated or field composting environments (adapted from Emadian et al. [43]).

\begin{tabular}{|c|c|c|c|c|c|c|c|c|c|}
\hline $\begin{array}{l}\text { Source of } \\
\text { Bioplastic }\end{array}$ & & Name of Bioplastic & Type of Environment & Conditions & Scale & $\begin{array}{l}\text { Biodegradation } \\
\text { Indicator }\end{array}$ & $\begin{array}{l}\text { Biodegradability } \\
(\%)\end{array}$ & $\begin{array}{c}\begin{array}{c}\text { Period of } \\
\text { Biodegradability } \\
\text { (Days) }\end{array} \\
\end{array}$ & Ref. \\
\hline \multirow{22}{*}{ Bio-based } & \multirow{14}{*}{ PLA-based } & PLA & Compost & $58^{\circ} \mathrm{C}$ & $\begin{array}{l}\text { lab-scale compost reactor (bottle of } 1 \mathrm{~L} \\
\text { volume) }\end{array}$ & Produced $\mathrm{CO}_{2}$ & 13 & 60 & [159] \\
\hline & & PLA & Compost & $65^{\circ} \mathrm{C}, \mathrm{pH}=8.5,63^{\circ} \%$ humidity & $\begin{array}{c}\text { Wooden box }(0.6 \mathrm{~m} \times 0.3 \mathrm{mx} 0.1 \mathrm{~m}) 1.2 \mathrm{~m} \\
\text { above ground and } 1 \mathrm{~m} \text { inside the compost } \\
\text { pile }\end{array}$ & Produced $\mathrm{CO}_{2}$ & 84 & 58 & [155] \\
\hline & & PLA & Compost & $55^{\circ} \mathrm{C}, 70 \%$ moisture & Laboratory scale composting setup & Produced $\mathrm{CO}_{2}$ & $\sim 70$ & 28 & [158] \\
\hline & & PLA & Compost & Aerobic, $58^{\circ} \mathrm{C}, 60 \%$ humidity & Lab-scale & Weight loss & 60 & 30 & [41] \\
\hline & & PLA & $\begin{array}{l}\text { Synthetic material containing } \\
\text { compost }\end{array}$ & Aerobic, $58^{\circ} \mathrm{C}$ & $\begin{array}{l}\text { Polypropylene reactor ( } \mathrm{L}=330 \mathrm{~mm}, \\
\mathrm{~W}=180 \mathrm{~mm}, \mathrm{H}=130 \mathrm{~mm})\end{array}$ & Weight loss & 63.6 & 90 & [15] \\
\hline & & PLA & $\begin{array}{l}\text { Synthetic material containing } \\
\text { compost }\end{array}$ & $58^{\circ} \mathrm{C}$ & Laboratory-scale plastic reactor & Weight loss & 100 & 28 & [56] \\
\hline & & PLA/PFF/starch (80/5/15\%)a & Compost & $58^{\circ} \mathrm{C}$ & $\begin{array}{l}\text { Lab-scale compost reactor (bottle of } 1 \mathrm{~L} \\
\text { volume) }\end{array}$ & Produced $\mathrm{CO}_{2}$ & 53 & 60 & [159] \\
\hline & & PLA/Soft wood $(70 / 30 \%)$ & Compost & Aerobic, $58^{\circ} \mathrm{C}, 60 \%$ humidity & - & Weight loss & 40 & 30 & [41] \\
\hline & & PLA/corn (90/10\%) & $\begin{array}{c}\text { Synthetic material containing } \\
\text { compost }\end{array}$ & Aerobic, $58^{\circ} \mathrm{C}$ & $\begin{array}{l}\text { Polypropylene reactor }(\mathrm{L}=330 \mathrm{~mm}, \\
\mathrm{W}=180 \mathrm{~mm}, \mathrm{H}=130 \mathrm{~mm})\end{array}$ & Weight loss & 79.7 & 90 & [15] \\
\hline & & $\mathrm{PLA}+\mathrm{Nano}-\mathrm{SiO}_{2}$ film & Composting & Aerobic, $58^{\circ} \mathrm{C}, 55 \%$ water & Reactor size of $37 \mathrm{~cm} \times 17 \mathrm{~cm} \times 25.5 \mathrm{~cm}$ & $\begin{array}{l}\text { Disintegration with } \\
\text { respect to PLA }\end{array}$ & 9.4 & 130 & [129] \\
\hline & & PLA+Clay film & Composting & Aerobic, $58^{\circ} \mathrm{C}, 55 \%$ water & Reactor size of $37 \mathrm{~cm} \times 17 \mathrm{~cm} \times 25.5 \mathrm{~cm}$. & $\begin{array}{l}\text { Disintegration with } \\
\text { respect to PLA }\end{array}$ & 34 & 130 & [129] \\
\hline & & $\mathrm{PLA}+\mathrm{Nano}-\mathrm{CaCO}_{3}$ film & Composting & Aerobic, $58^{\circ} \mathrm{C}, 55 \%$ water & Reactor size of $37 \mathrm{~cm} \times 17 \mathrm{~cm} \times 25.5 \mathrm{~cm}$. & $\begin{array}{l}\text { Disintegration with } \\
\text { respect to PLA }\end{array}$ & 48 & 130 & [129] \\
\hline & & PLA/PHB $(75 / 25 \%)$ & $\begin{array}{c}\text { Synthetic material containing } \\
\text { compost }\end{array}$ & $58^{\circ} \mathrm{C}$ & Laboratory-scale plastic reactor & Weight loss & 100 & 35 & [56] \\
\hline & & PLA/corn (90/10\%) & $\begin{array}{l}\text { Synthetic material containing } \\
\text { compost }\end{array}$ & Aerobic, $58^{\circ} \mathrm{C}$ & $\begin{array}{l}\text { Polupropylene reactor }(\mathrm{L}=330 \mathrm{~mm}, \\
\mathrm{W}=180 \mathrm{~mm}, \mathrm{H}=130 \mathrm{~mm})\end{array}$ & Weight loss & 79.7 & 90 & [15] \\
\hline & \multirow[t]{3}{*}{ PHA-based } & PHA & Soil/compost $(90 / 10 \%)$ & $25^{\circ} \mathrm{C}, 65 \%$ humidity & Lab-scale desiccator & Produced $\mathrm{CO}_{2}$ & $40-50$ & 15 & [117] \\
\hline & & PHB & Compost & $58^{\circ} \mathrm{C}$ & Static composting vessel & Produced $\mathrm{CO}_{2}$ & 79.9 & 110 & [157] \\
\hline & & PHB & Compost & $55^{\circ} \mathrm{C}, 70 \%$ moisture & Laboratory scale composting setup & Produced $\mathrm{CO}_{2}$ & $\sim 80$ & 28 & [158] \\
\hline & \multirow{5}{*}{ Starch-based } & Bioplastic (made from potato almidon) & Compost & Aerobic, $58^{\circ} \mathrm{C}$ & Laboratory-scale test with PP reactors & Weight loss & $\sim 85$ & 90 & {$[4]$} \\
\hline & & Mater-Bi bioplastic ( $60 \%$ starch + $40 \%$ resin) & Compost & Aerobic, $23^{\circ} \mathrm{C}, 55 \%$ moisture & $\begin{array}{l}\text { A PVC rotary drum, } \mathrm{L}=95 \mathrm{~cm} \& \mathrm{D}_{\mathrm{i}}=55 \\
\text { cm with } 200 \mathrm{~L} \text { capacity }\end{array}$ & Weight loss & 26.9 & 72 & [26] \\
\hline & & Plastarch & Compost & Aerobic, $55^{\circ} \mathrm{C}, 60 \%$ moisture & $4 \mathrm{~L}$ vessel made of PVC pipe & Produced $\mathrm{CO}_{2}$ & 50 & 85 & [54] \\
\hline & & Mater-Bi plastic carrier bags & Compost & $25^{\circ} \mathrm{C}$ & Lab-scale cylinder $(30-20 \mathrm{~cm})$ & Weight loss & 43 & 90 & {$[22]$} \\
\hline & & Cassava starch/glycerol (3/1) & Compost soil & $\begin{array}{l}\begin{array}{l}\text { Soil Burial Test., room } \\
\text { temperature }\end{array} \\
\text {. }\end{array}$ & Lab-scale & Weight loss & 30 & 10 & [150] \\
\hline
\end{tabular}


Table 5. Cont

\begin{tabular}{|c|c|c|c|c|c|c|c|c|c|}
\hline $\begin{array}{l}\text { Source of } \\
\text { Bioplastic }\end{array}$ & & Name of Bioplastic & Type of Environment & Conditions & Scale & $\begin{array}{l}\text { Biodegradation } \\
\text { Indicator }\end{array}$ & $\begin{array}{l}\text { Biodegradability } \\
(\%)\end{array}$ & $\begin{array}{c}\text { Period of } \\
\text { Biodegradability } \\
\text { (Days) }\end{array}$ & Ref. \\
\hline & \multirow{8}{*}{ Cellulose-based } & $\mathrm{CA}$ (produced from fiber flax) & $\begin{array}{c}\text { Municipal solid waste mixture } \\
\text { (compost) }\end{array}$ & - & $\begin{array}{l}\text { Bench-scale simulated composting, batch } \\
\text { reaction vessel }\end{array}$ & Weight loss & 44 & 14 & [63] \\
\hline & & CA (produced from cotton linters) & $\begin{array}{l}\begin{array}{l}\text { Municipal solid waste mixture } \\
\text { (compost) }\end{array}\end{array}$ & - & $\begin{array}{l}\text { Bench-scale simulated composting, batch } \\
\text { reaction vessel }\end{array}$ & Weight loss & 35 & 14 & [63] \\
\hline & & $\begin{array}{l}\text { Sponge cloth from renewable resources, organic } \\
\text { cotton mesh }\end{array}$ & Compost & $\begin{array}{c}1 \mathrm{~m} \text { depth- } 15.7^{\circ} \mathrm{C} \text { average } \\
\text { outside temperature }\end{array}$ & Industrial scale & Weight loss & 20 & 84 & [51] \\
\hline & & $\begin{array}{l}\text { Sponge cloth (Cellulose, Cotton mesh, Water, } \\
\text { Salts, Pigments) }\end{array}$ & Compost & $\begin{array}{l}1 \mathrm{~m} \text { depth }-15.7^{\circ} \mathrm{C} \text { average } \\
\text { outside temperature }\end{array}$ & Industrial scale & Weight loss & 80 & 84 & [51] \\
\hline & & Sponge cloth (70\% Cellulose, 30\% Cotton) & Compost & $\begin{array}{c}1 \mathrm{~m} \text { depth }-15.7^{\circ} \mathrm{C} \text { average } \\
\text { outside temperature }\end{array}$ & Industrial scale & Weight loss & $\approx 100$ & 84 & [51] \\
\hline & & Sponge cloth ( $75 \%$ Cellulose, $25 \%$ Cotton) & Compost & $\begin{array}{c}1 \mathrm{~m} \text { depth }-15.7^{\circ} \mathrm{C} \text { average } \\
\text { outside temperature }\end{array}$ & Industrial scale & Weight loss & $\approx 100$ & 84 & [51] \\
\hline & & Sponge cloth (cellulose-based) & $\begin{array}{c}\text { Synthetic material containing } \\
\text { compost }\end{array}$ & Aerobic, $58^{\circ} \mathrm{C}$ & $\begin{array}{l}\text { Laboratory-scale controlled composting } \\
\text { conditions }\end{array}$ & Weight loss & $>80$ & 154 & [73] \\
\hline & & $\mathrm{Nylon}_{4}$ (Polyamides, Bio-based) & Composted soil & $\begin{array}{l}25^{\circ} \mathrm{C}, \mathrm{pH}=7.5-7.6, \\
80 \% \text { humidity }\end{array}$ & Buried in containers made of $\mathrm{PP}$ & Weight loss & 100 & 120 & {$[133]$} \\
\hline \multirow{7}{*}{ Petroleum-based } & \multirow{5}{*}{ PBS-based } & PBS & Compost & $\begin{array}{l}\text { Aerobic, } 58-65^{\circ} \mathrm{C}, \mathrm{pH}=7-8, \\
50-55 \% \text { moisture }\end{array}$ & $\begin{array}{l}\text { Glass hermetic flask with a capacity of } \\
1000 \mathrm{~mL}\end{array}$ & Produced $\mathrm{CO}_{2}$ & 90 & 160 & [35] \\
\hline & & PBS/soy meal (75/25\%) & Compost & $\begin{array}{l}\text { Aerobic, } 58-60^{\circ} \mathrm{C}, \mathrm{pH}=7-8, \\
50-55 \% \text { moisture }\end{array}$ & $\begin{array}{l}\text { Glass hermetic flask with a capacity of } \\
1000 \mathrm{~mL}\end{array}$ & Produced $\mathrm{CO}_{2}$ & 90 & 100 & [35] \\
\hline & & PBS/canola meal $(75 / 25 \%)$ & Compost & $\begin{array}{l}\text { Aerobic, } 58-60^{\circ} \mathrm{C}, \mathrm{pH}=7-8, \\
50-55 \% \text { moisture }\end{array}$ & $\begin{array}{l}\text { Glass hermetic flask with a capacity of } \\
1000 \mathrm{~mL}\end{array}$ & Produced $\mathrm{CO}_{2}$ & 90 & 100 & [35] \\
\hline & & PBS/corn gluten meal $(75 / 25 \%)$ & Compost & $\begin{array}{l}\text { Aerobic, } 58-60^{\circ} \mathrm{C}, \mathrm{pH}=7-8, \\
50-55 \% \text { moisture }\end{array}$ & $\begin{array}{l}\text { Glass hermetic flask with a capacity of } \\
1000 \mathrm{~mL}\end{array}$ & Produced $\mathrm{CO}_{2}$ & 90 & 100 & [35] \\
\hline & & $\mathrm{PBS} /$ switch grass $(75 / 25 \%)$ & Compost & $\begin{array}{l}\text { Aerobic, } 58-60^{\circ} \mathrm{C}, \mathrm{pH}=7-8, \\
50-55 \% \text { moisture }\end{array}$ & $\begin{array}{l}\text { Glass hermetic flask with a capacity of } \\
1000 \mathrm{~mL}\end{array}$ & Produced $\mathrm{CO}_{2}$ & 90 & 170 & [35] \\
\hline & \multirow[b]{2}{*}{ PCL-based } & PCL/starch & Compost & Aerobic, $25^{\circ} \mathrm{C}$ & $500 \mathrm{~mL}$ glass bottle & Produced $\mathrm{CO}_{2}$ & 88 & 44 & [1] \\
\hline & & PCL & Compost & Aerobic, $50^{\circ} \mathrm{C}, \mathrm{pH}=7-8.5$ & $\begin{array}{l}\text { Experimental system, mini-reactor with a } \\
\text { cylinder made of pyrex glass and rubber } \\
\text { stoppers with glass pipes for aeration }\end{array}$ & Produced $\mathrm{CO}_{2}$ & 38 & 6 & {$[112$} \\
\hline
\end{tabular}




\subsection{Anaerobic Biodegradation of Bioplastics}

The importance of evaluating the biodegradability of bioplastics in anaerobic conditions is mainly related to the presence of food packaging not often sorted (although biodegradable) from food-waste, with the latter used as substrate in AD plant [160] or to the use of compostable bags used to collect food waste in separate collection systems [16].

Under anaerobic conditions, the biodegradation's process results in the production of biogas, water, hydrogen sulfide, ammonia, and digestate via microbial metabolism in the absence of oxygen. Deterioration of organic materials and thus bioplastics, under anaerobic conditions and specifically in an AD plant, offer some notable advantages over the aerobic composting. For instance, the limitation of odor emission, the produced methane can be used as an energy source [161], as well as the nutrient-rich digestate residue, which can be used as a fertilizer.

The rate of biodegradation under anaerobic conditions is generally assessed via the produced biogas and therefore measured in $\mathrm{mL} \mathrm{CH}_{4} \mathrm{gVS}^{-1}$ day $^{-1}$.

The schematic reaction is presented below $[77,161]$ :

$$
\text { Organic matter }+\mathrm{H}_{2} \mathrm{O}+\text { Nutrients } \rightarrow \text { Digestate }+\mathrm{CH}_{4}+\mathrm{CO}_{2}+\mathrm{NH}_{3}+\mathrm{H}_{2} \mathrm{~S}+\text { Heat }
$$

In anaerobic digesters, bioplastics degrade mainly via enzymatic hydrolysis as microorganisms secrete external enzymes into the digestion medium where long-chain polymers are converted into oligomers and monomers. The oligomers and monomers, which are small molecules, then diffuse through the cell wall and are further broken down by the action of internal enzymes. Furthermore, in anaerobic digestion, bioplastics can play a substantial role in enhancing the digestion process [116]. This is because the organic waste stream of AD is mostly biowaste, such as kitchen or food waste, which are typically rich in nitrogen. Thus, $\mathrm{C} / \mathrm{N}$ can be less than 15 , which is not ideal for anaerobic digestion processes since it results in the generation of the toxic ammonia. As a result, adding bioplastics to the mixture can increase the carbon-rich substrate and thus the $\mathrm{C} / \mathrm{N}$ ratio to optimal values [52]. It is important to mention that it is not rare that some bioplastics may only disintegrate during the anaerobic phase and achieve ultimate biodegradation under the aerobic phase that usually follows or when the digestate is applied to soil.

Among the process parameters, temperature plays a crucial role as mesophilic conditions do not allow a satisfying disintegration of the material, independently of the duration of the test $[54,77,111,162]$. Higher mass loss and disintegration have been found in thermophilic conditions $[77,122,163]$. The international standards ASTM D5511-02 and ISO 13975 for the definition of the biodegradation of plastics and bioplastics include thermophilic conditions. Some other standards, though (see paragraph "4. Standardization and Certification of Bioplastics"), refer to mesophilic temperatures [127].

The European Committee for Standardization (CEN) in the guideline EN 13432:2000 states that for anaerobic degradation, at least $50 \%$ of the substance needs to be converted into biogas (based on the theoretical maximum value) over a two-month period [116]. However, it should be noticed that the hydraulic residence time (HRT) in AD plants is lower than 30 days [77]. As consequence, the degree of biodegradation required by the EN 13432 norm may not be achieved. In this case, the use of thermal alkaline treatment [164], such as the addition of calcium carbonate [160] at low concentrations, improved their biodegradation rates under anaerobic environments by providing a pathway for microbial activity. The author of [160] outlined how only after alkaline pretreatment can a significant degradation ( $>50 \%$ ) be obtained in 15-30 days [77]. Moreover, co-digestion of PLA with food-waste increased the methane potential of 10\% [160], but resulted in a low degradation rate (29-49\%) as well as for PCL (3-22\%) even after extremely long HRTs (277 days) [161].

Indicatively, some of the biopolymers that have been reported to biodegrade under anaerobic conditions are PHA, PHB, starch-blends, cellulose, PLA, PCL, PBS, and PVA.

It is essential to note that each biodegradable bio-polymer, according to its chemical composition and design, has a different rate of biodegradation, which is affected by the conditions of the plant $[28,116]$. 
For example, PLA biodegrades better under thermophilic $\left(50-70^{\circ} \mathrm{C}\right)$ conditions, in contrast to PHA that biodegrades better under mesophilic conditions $\left(35-40^{\circ} \mathrm{C}\right)$. Calabrò et al. [77] underlined how compostable bags made of Mater-Bi (starch derived bioplastic) are only partially degraded under normal HRT. Moreover, it has been found that the rate of biodegradation amongst some of the previously mentioned biopolymers follows this order (from least to most biodegradable): PVA $<$ PLA $<$ PCL $<$ PBS [116].

Moreover, the two-stage fermentation AD process has recently gained attention to enhance VFAs production as they can be used for production of PHA as well as other biofuels and biochemicals [82,165].

Table 6 summarizes several studies on anaerobic biodegradation of bioplastics. PHB was found to be suitable for $\mathrm{AD}$ as $90 \%$ of the material was degraded in nine days of digestion in the anaerobic sludge, while PBS remained stable under the same conditions $[161,166]$. PHA-based polymers generally showed a biodegradability over $75 \%$ in less than two months [111,122,160,167], while starch-based bio-polymers showed a lower performance $[54,77]$ compared to PHA.

PHA bioplastics were well degraded under both aerobic and anaerobic environments $[43,82,116]$. Moreover, the use of biopolymers such as PHA and thermoplastic starch can improve the biodegradation rate of anaerobic digesters as they fast degrade into polylactic acid [160].

With regards to the use of the digestate as fertilizer, it is generally thought that it may contribute to the release of microplastics to soil [8]. On the other hand, environmental conditions present in soil could aid bioplastics to completely biodegrade.

\subsection{Biodegradation of Bioplastics in Aquatic Environments}

The plastic waste pollution of fresh and marine waters is one of the most severe threats of the century, considering that although approximately $70-80 \%$ of the waste originates on land, large plastic waste quantities are detected in the oceans [16]. Biodegradation within aquatic habitats varies and depends mainly on the environmental conditions, such as temperature and the presence of nutrients [19,43,125]. Not many studies have been conducted on the biodegradation of bioplastics (e.g., PLA) under aquatic conditions compared to the widely investigated terrestrial systems $[3,38]$. The decomposition of polymers within an aquatic environment can vary due to the many different existing conditions. It is worth to point out that biodegradation in aquatic environments can be both aerobic and anaerobic, even though most studies reported in the literature refer to aerobic conditions (Table 7).

Moreover, it is possible to distinguish the following liquid (or water) environment where biological processes occur: Fresh water (lakes, river) and marine environments (pelagic domain, eulittoral zone, sandy sublittoral zone, sandy supralittoral zone, bottom of the deep sea, and sediments). Different sea waters might also have different bioplastic-degrading microbes presence, which are a key factor to biodegradation $[3,43]$. This is due to the different environments, that is the value of the waters' parameters like temperature and $\mathrm{pH}$, which vary according to the different habitats [143].

In a study conducted by Tosin et al. [3], it was found that to assess the biodegradation behavior there were six available test methods corresponding to each one of the above mentioned aquatic habitats. It was found that when simulating the habitat of sandy sublittoral zone, where sunlight reaches the ocean floor (benthic zone) and there is oxygen consumption, which means aerobic conditions, Mater-Bi was biodegraded [3].

Biodegradation rate has been found to be higher in seawater, and particularly at the interface of water-sediment, rather than in fresh water ponds and rivers [134]. Moreover, the raw material used to produce the polymer also affects the ability of the microorganisms to attack the substrate. This may be the reason that polymers obtained from natural organisms easily degrade compared to synthetic biopolyesters, since the number of organisms able to attach their chemical structure is limited [145].

Mater-Bi, PHA, and PCL, according to [20,28], are able to biodegrade in marine water. In a study carried out in tropical marine environments, the size and shape of the PHB polymers were found to influence their degradation more than their chemical composition; specifically, thinner and smaller items degraded faster than compact pellets [134]. 
Table 6. Studies carried out on bioplastics' degradation in anaerobic conditions (adapted from Emadian et al. [43]).

\begin{tabular}{|c|c|c|c|c|c|c|c|c|c|}
\hline $\begin{array}{l}\text { Source of } \\
\text { Bioplastic }\end{array}$ & & f Bioplastic & Type of Environment & Conditions & Scale & $\begin{array}{l}\text { Biodegradation } \\
\text { Indicator }\end{array}$ & $\underset{(\%)}{\text { Biodegradability }}$ & $\begin{array}{c}\text { Period of } \\
\text { Biodegradability } \\
\text { (Days) }\end{array}$ & Ref. \\
\hline \multirow{15}{*}{ Bio-based } & \multirow{6}{*}{ PLA-based } & PLA & Sludge & Anaerobic, $37^{\circ} \mathrm{C}$ & $\begin{array}{l}\text { Lab-scale, } 10 \mathrm{~L} \text { stainless } \\
\text { steel bottle }\end{array}$ & Produced $\mathrm{CO}_{2}$ & $29-49$ & 277 & [161] \\
\hline & & PLA & Sludge & Anaerobic, $55^{\circ} \mathrm{C}$ & $\begin{array}{l}\text { Lab-scale, } 10 \mathrm{~L} \text { stainless } \\
\text { steel bottle }\end{array}$ & Produced $\mathrm{CO}_{2}$ & 80 & $30-50$ & [111] \\
\hline & & PLA & $\mathrm{AD}$ & Anaerobic, $52^{\circ} \mathrm{C}$ & Lab-scale & $\begin{array}{l}\text { Comparison with } \\
\text { respect to theoretical } \\
\text { BMP }\end{array}$ & 90 & 36 & [160] \\
\hline & & PLA powder & Sludge & Anaerobic, $55^{\circ} \mathrm{C}$ & Lab-scale & Biogas production & 90 & 60 & {$[167]$} \\
\hline & & PLA & Sludge & Anaerobic, $55^{\circ} \mathrm{C}$ & Lab-scale & n.a. & 75 & 75 & [163] \\
\hline & & PLA & Sludge & Anaerobic, $55^{\circ} \mathrm{C}$ & Lab-scale, 10-L bottle & Produced biogas & 85 & 60 & [122] \\
\hline & \multirow{5}{*}{ PHA-based } & PHBs & $\mathrm{AD}$ & $\begin{array}{c}\text { Anaerobic } \\
\text { digestion-untreated } \\
\text { PHB- } 35^{\circ} \mathrm{C}\end{array}$ & Lab-scale & Conversion to biogas & 67 & 175 & [164] \\
\hline & & PHBs & $\mathrm{AD}$ & $\begin{array}{c}\text { Anaerobic } \\
\text { digestion-pretreated } \\
\text { PHB- } 35^{\circ} \mathrm{C}\end{array}$ & Lab-scale & Conversion to biogas & 91 & 175 & [164] \\
\hline & & PHB & Sludge & Anaerobic, $55^{\circ} \mathrm{C}$ & Lab-scale & Produced biogas & 90 & 14 & [163] \\
\hline & & PHB & Sludge & Anaerobic, $37^{\circ} \mathrm{C}$ & $\begin{array}{l}\text { Lab-scale, } 10 \text { L stainless } \\
\text { steel bottle }\end{array}$ & Produced $\mathrm{CO}_{2}$ & 90 & 9 & [161] \\
\hline & & PHB & $\mathrm{AD}$ & Anaerobic & Lab-scale & $\begin{array}{l}\text { Weight loss-Biogas } \\
\text { production }\end{array}$ & 90 & 9 & [166] \\
\hline & \multirow{4}{*}{ Starch-based } & Plastarch & $\mathrm{AD}$ & Anaerobic, $37^{\circ} \mathrm{C}$ & $\begin{array}{l}2 \mathrm{~L} \text { laboratory scale } \\
\text { batch reactor }\end{array}$ & Produced $\mathrm{CO}_{2}$ & 26.4 & 50 & [54] \\
\hline & & Mater-Bi plastic carrier bags & $\mathrm{AD}$ & $\begin{array}{c}\text { Untreated } \\
\text { bioplastic }-35^{\circ} \mathrm{C}\end{array}$ & Lab-scale 1-L bottle & Weight loss & $23-30$ & $15-30$ & [77] \\
\hline & & Mater-Bi plastic carrier bags & $\mathrm{AD}$ & $\begin{array}{l}\mathrm{NaOH} \text { pretreated } \\
\text { bioplastic- } 35^{\circ} \mathrm{C}\end{array}$ & Lab-scale 1-L bottle & Weight loss & 73 & 15 & [77] \\
\hline & & Mater-Bi plastic carrier bags & $\mathrm{AD}$ & $\begin{array}{c}\text { Untreated } \\
\text { bioplastic- } 55^{\circ} \mathrm{C}\end{array}$ & Lab-scale 1-L bottle & Weight loss & $28-41$ & $15-30$ & [77] \\
\hline \multirow{4}{*}{ Petroleum-based } & PBS-based & PBS & Landfill & Anaerobic, $25^{\circ} \mathrm{C}$ & $500 \mathrm{~mL}$ glass bottle & Produced $\mathrm{CO}_{2}$ & 2 & 100 & [1] \\
\hline & \multirow{3}{*}{ PCL-based } & PCL/starch & Landfill & Anaerobic, $25^{\circ} \mathrm{C}$ & $500 \mathrm{~mL}$ glass bottle & Produced $\mathrm{CO}_{2}$ & 83 & 139 & [1] \\
\hline & & PCL & Sludge & Anaerobic, $37^{\circ} \mathrm{C}$ & $\begin{array}{l}\text { Lab-scale, } 10 \text { L stainless } \\
\text { steel bottle }\end{array}$ & Produced $\mathrm{CO}_{2}$ & $3-22$ & 277 & [161] \\
\hline & & PCL & Sludge & Anaerobic, $55^{\circ} \mathrm{C}$ & $\begin{array}{l}\text { Lab-scale, } 10 \mathrm{~L} \text { stainless } \\
\text { steel bottle }\end{array}$ & Produced $\mathrm{CO}_{2}$ & 75 & $40-75$ & [161] \\
\hline
\end{tabular}


Table 7. Studies carried out on bioplastics' degradation in aquatic environments (adapted from Emadian et al. [43]).

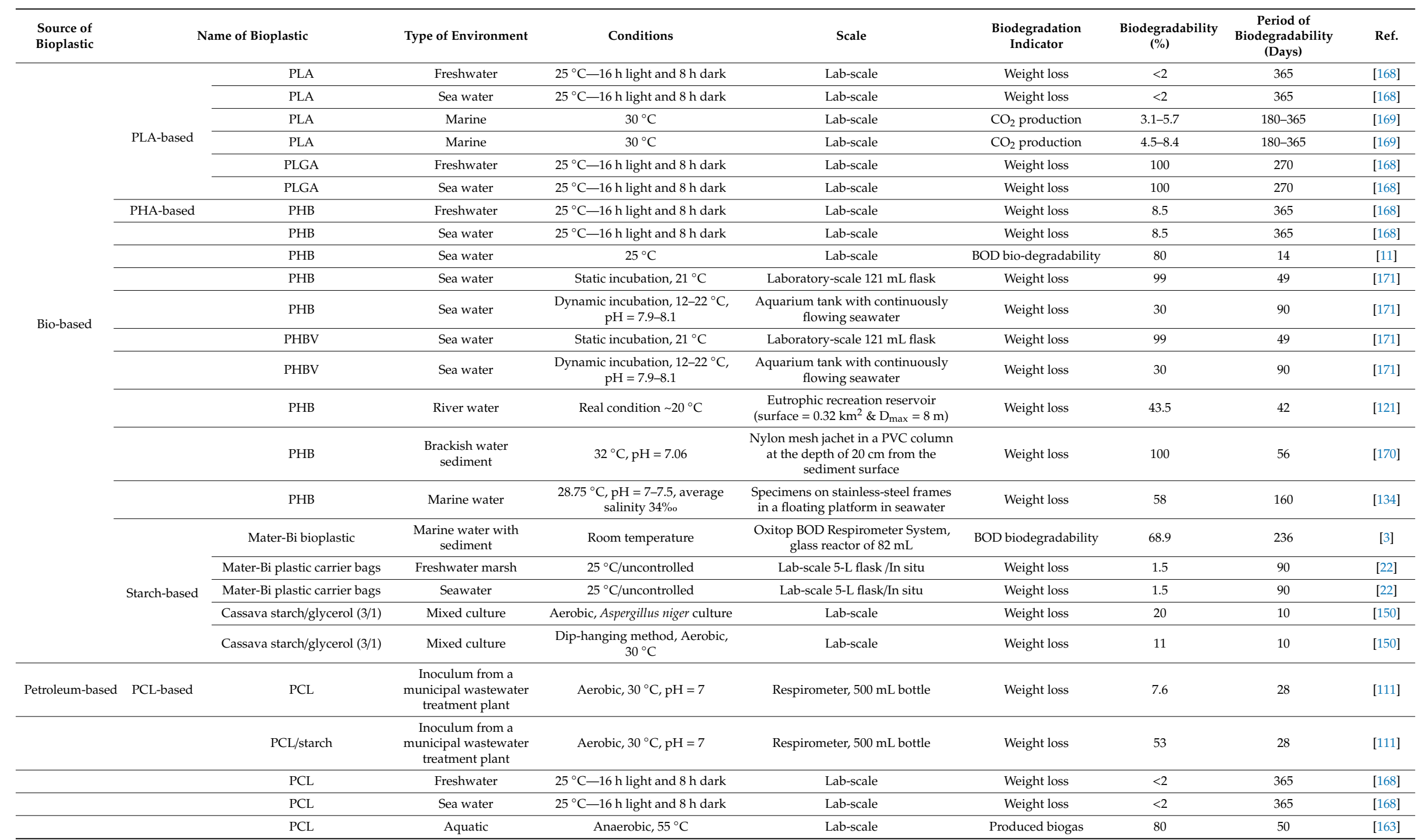


Table 7 summarizes the experiences carried out on bioplastics' degradation in aquatic environments. Müller [147] observed a complete fragmentation of PCL in sea water at temperature of $9-21{ }^{\circ} \mathrm{C}$ in 56 days. Conversely, in a study by Bagheri et al. [168], PCL and PLA showed no degradation in artificial seawater at $25^{\circ}$; PHB showed a degradation of less than $10 \%$ over a period of one year while PLGA was completely degraded (100\% after 270 days). Therefore, results for PCL are often contradictory and are probably dependent on the study conditions. PLA-based bioplastics showed low biodegradability: Less than $2 \%$ after one year in both fresh and sea water [168]; in [169], a degradation of 3 and $8 \%$ was measured in a marine environment after 6 and 12 months, respectively. Biodegradation of PHB and PHBV in seawater was complete $(100 \%)$ after two months [170,171].

For PHAs polymers and copolymers (such as PHB and PHBV), high degrees of degradation were recorded during a period of 400 days regardless of the type of water (sea water, tropical coast water, and sweet water) and temperature $\left(6\right.$ to $\left.32^{\circ} \mathrm{C}\right)$ [147].

PCL-based bioplastics showed variable degrees of low biodegradability, i.e., from less than $2 \%$ in one year [168] to $80 \%$ in 50 days [163].

\subsection{Comparison of Different Degradation Environments}

A classification of the studies carried out on bioplastics' degradation in different environments is shown in Figure 2.

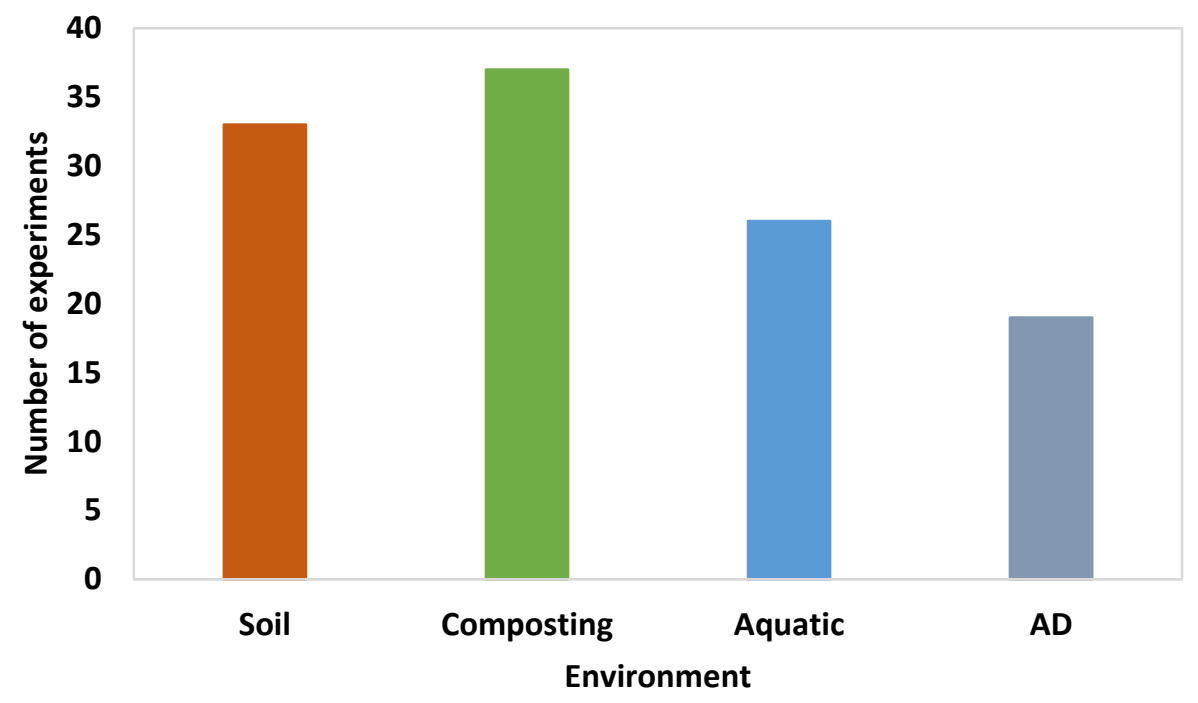

Figure 2. Classification of the experiments presented in Tables 4-7, according to the conditions in which they were performed.

Approximately $83 \%$ of the performed experiments took place in aerobic environments (Figure 2). It is worth mentioning that $43 \%$ of those experiments that were performed under aerobic conditions presented an extent of biodegradation over $60 \%$. In addition, most of the aerobic-condition experiments took place in compost (39\%), followed by soil (34\%), and aquatic $(27 \%)$ environments. On the contrary, only $17 \%$ of the total experiments included in the above tables took place in anaerobic environments. Even though their extents of biodegradation ranged from 2 to $91 \%$, more than half of them $(68 \%)$ achieved over $65 \%$ biodegradability.

However, the conditions of the experiments studied here vary a lot, and to make a clear comparison among them is difficult. The experiments carried out in compost or in anaerobic digestion environments show a biodegradability over $50 \%$ in 65 and $68 \%$ of the cases, respectively. For those carried out in aquatic environments, this share is $44 \%$ and for experiments carried out in soil, it is $33 \%$ (of the cases). 


\section{Standardization and Certification of Bioplastics}

Since biopolymers are indistinguishable from the conventional plastics, it is wise to provide a mechanism ensuring their quality and labelling. Standardization and certification systems assign rules, namely standards, that a product must comply with before it can obtain a certain label. For instance, the European EN 16785-1,2 norm defines the requirements and methods for determining the bio-based content of a given product.

However, it should be noted that there is not a universal biodegradation procedure to assess biodegradability for every type of bioplastic regarding all of the previously mentioned kind of environments [134]. Table 8 reports several of the available standards for the evaluation of plastics' compostability and biodegradability.

The large variety of standards, products, and services associated with bioplastics and their biodegradation categories [52] are summarized as followed:

- Industrial composting, such as EN 13432, EN 14995, ISO 18606 and ISO 17088;

- Home composting, such as the Australian Norm AS 5810 and the French Norm NF T 51-800;

- Biodegradability in anaerobic environment, such as ISO 11734, ISO 14853, ISO 15985, ASTM D5210-92, ASTM D5511-02, ASTM D5526-94D;

- Biodegradability in soils, such as EN 17033 and ASTM D5988-03;

- Biodegradability in marine environments ASTM D708, ASTM D6691, ASTM D6692, ASTM D7473, OECD 306, and ISO 16221.

When it comes to the certification of bioplastics, independent certificates for biodegradable plastics are issued by DIN Certco and Vinçotte [28] in Europe. DIN Certco issues certificates for compostable plastics based on the EN 14995 (or ISO 17088) and for compostable packaging based on the EN 13432 (or ASTM D6400) standard. Vinçotte issues certificates for compostable plastics based on EN 13432, and also certificates for plastics that can be composted in home composting (OK home composting) and plastics that biodegrade in soil (OK biodegradable SOIL) and water (OK biodegradable WATER) [33,43]. Certificates for compostable plastics are also issued by the Biodegradable Products Institute (BPI, US) and the Japan BioPlastics Association (JBPA, Japan) as well as other less widely used organizations [172].

Regarding anaerobic biodegradation, standardization is not fully developed and is still in an early stage. Moreover, there exist no particular certificates and labels on anaerobic treatability $[52,116]$.

Apart from physico-chemical analysis of compost to assess its quality, phytotoxicity tests carried out according to the OECD Guideline for Testing of Chemicals [173] are necessary (although not mandatory) for monitoring the germination/growth rate of plants in compost with degraded bioplastics [127]. 
Table 8. Main standards utilized for assessing biodegradation in different environments.

\begin{tabular}{|c|c|c|}
\hline $\begin{array}{c}\text { Environment or } \\
\text { Process }\end{array}$ & Standard & Notes/Requirements \\
\hline \multirow{13}{*}{ Composting } & EN 13432 & $\begin{array}{l}\text { Criteria that must be taken into account to label a packaging material as compostable: at least } 90 \% \text { of the organic material is converted into } \mathrm{CO}_{2} \text { within } 6 \text { months; after } 3 \text { months' composting and } \\
\text { subsequent sieving through a } 2 \mathrm{~mm} \text { sieve, no more than } 10 \% \text { residue may remain, as compared to the original mass; no negative influence on the composting process or plant growth is permitted. } \\
\text { Biodegradability is evaluated by } \mathrm{O}_{2} \text { consumption and } \mathrm{CO}_{2} \text { generation. }\end{array}$ \\
\hline & ISO 17088 & $\begin{array}{l}\text { This specification is intended to establish the requirements for the labelling of plastic products and materials, including packaging made from plastics, as "compostable" or "compostable in municipal } \\
\text { and industrial composting facilities" or "biodegradable during composting". }\end{array}$ \\
\hline & ASTM D6400 & $\begin{array}{l}\text { The standard lasts from a minimum of } 90 \text { days to up to } 180 \text { days This standard includes elemental analysis, phytotoxicity tests, and mesh filtration of the resulting particles, necessary for labeling of } \\
\text { plastics designed to be aerobically composted in municipal or industrial facilities. }\end{array}$ \\
\hline & ASTM D6868 & $\begin{array}{l}\text { Standard specification for labeling of end items that incorporate plastics and polymers as coatings or additives with paper and other substrates designed to be aerobically composted in municipal or } \\
\text { industrial facilities. }\end{array}$ \\
\hline & ASTM D5338 & $\begin{array}{l}\text { This test method determines the degree and rate of aerobic biodegradation of plastic materials on exposure to a controlled-composting environment under laboratory conditions, at thermophilic } \\
\text { temperatures. } \\
\text { This test method is designed to yield a percentage of conversion of carbon in the sample to carbon dioxide. }\end{array}$ \\
\hline & ISO 14855 & $\begin{array}{l}\text { The standard determines ultimate aerobic biodegradability and disintegration of plastic materials under controlled composting conditions. } \\
\text { Test requirements include standard testing for a minimum of } 90 \text { days and then the biodegradation results are determined after an analysis of evolved } \mathrm{CO}_{2} \text {. }\end{array}$ \\
\hline & ISO 20200 & $\begin{array}{l}\text { The standard specifies a method of determining the degree of disintegration of plastic materials when exposed to a laboratory-scale composting environment. The method is not applicable to the } \\
\text { determination of the biodegradability of plastic materials under composting conditions. Further testing is necessary to be able to claim compostability. }\end{array}$ \\
\hline & ISO 16929 & $\begin{array}{l}\text { The standard is used to determine the degree of disintegration of plastic materials in a pilot-scale aerobic composting test under defined conditions. It cannot be used to determine the aerobic } \\
\text { biodegradability of a test material. }\end{array}$ \\
\hline & EN 14806 & $\begin{array}{l}\text { This laboratory scale test method using synthetic waste aims at simulating the environmental conditions found in industrial composting plants to assess the disintegration process of packaging } \\
\text { materials exposed to this environment. This test does not replace the acceptance disintegration test as specified in EN 14045, in accordance with EN } 13432 \text {. }\end{array}$ \\
\hline & EN 14045 & $\begin{array}{l}\text { This standard is used to evaluate the disintegration of packaging materials in a pilot-scale aerobic composting test under defined conditions. The material is mixed with biowaste and spontaneously } \\
\text { composted for } 12 \text { weeks. Disintegration is measured by the calculation of a mass balance. Additionally, this method can be used for visual perception and photographic documentation of the } \\
\text { disintegration of packaging materials and to evaluate the effect of their addition on the composting process. } \\
\text { Other methods should be used to measure the biodegradability of the packaging materials. }\end{array}$ \\
\hline & AS 5810 & $\begin{array}{l}\text { This Australian standard specifies requirements and procedures to determine whether a plastic material is biodegradable in home composting conditions and provides the basis to allow labelling of } \\
\text { materials or products made from plastics as 'home compostable', for use in home composting systems. }\end{array}$ \\
\hline & UNI 11183 & The norm defines the biodegradability requirements of plastic materials to be anaerobically treated at room temperature. \\
\hline & NF T 51-800 & French norm specifying the requirements for plastics suitable for home composting. \\
\hline \multirow{2}{*}{$\begin{array}{l}\text { Composting and } \\
\text { anaerobic digestion } \\
\text { (AD) }\end{array}$} & ISO 18606 & $\begin{array}{l}\text { As with EN 13432, packaging is considered recoverable by organic recycling only if all the individual components meet the requirements. } \\
\text { For each of the packaging components the following four aspects are addressed: biodegradation; disintegration during biological waste treatment process; negative effects on the biological process; } \\
\text { negative effects on the quality of the resulting compost, including the presence of high levels of regulated metals and other substances hazardous to the environment. }\end{array}$ \\
\hline & EN 14995 & $\begin{array}{l}\text { Requirements and procedures for the evaluation of the compostability and anaerobic treatment of plastics. Disintegration of the material during the biological treatment and effect on the quality of the } \\
\text { final product are considered indexes of biodegradability. }\end{array}$ \\
\hline
\end{tabular}


Table 8. Cont.

\begin{tabular}{|c|c|c|}
\hline $\begin{array}{l}\text { Environment or } \\
\text { Process }\end{array}$ & Standard & Notes/Requirements \\
\hline \multirow{4}{*}{ Soil } & EN 17033 & This document specifies the requirements for biodegradable films, manufactured from thermoplastic materials, to be used for mulch applications in agriculture and horticulture. \\
\hline & NF U 52-001 & French standard used for the classification of biodegradable materials for agriculture and horticulture purposes (mulching products) \\
\hline & ISO 17556 & $\begin{array}{l}\text { This document specifies a method for determining the ultimate aerobic biodegradability of plastic materials in soil by measuring the oxygen demand in a closed respirometer or the amount of carbon } \\
\text { dioxide evolved. } \\
\text { If a non-adapted soil is used as an inoculum, the test simulates the biodegradation processes which take place in a natural environment; if a pre-exposed soil is used, the method can be used to } \\
\text { investigate the potential biodegradability of a test material. }\end{array}$ \\
\hline & ASTM D5988-18 & This test method determines the degree of aerobic biodegradation by measuring evolved carbon dioxide as a function of time for a plastic exposed to soil. \\
\hline AD-Landfilling & ASTM D5511-02 & $\begin{array}{l}\text { This test method covers the determination of the degree and rate of anaerobic biodegradation of plastic materials in high-solids environments (more than } 30 \% \text { total solids) under anaerobic conditions } \\
\text { and static non-mixed conditions. The methanogenic inoculum is derived from anaerobic digesters operating only on pretreated household waste. } \\
\text { This test method may also resemble some conditions in biologically active landfills where the gas generated is recovered and biogas production is even actively promoted. }\end{array}$ \\
\hline Landfilling & ASTM D5526 & The standard evaluates the percentage of conversion of carbon in the test sample to carbon in the gaseous form $\left(\mathrm{CH}_{4}\right.$ and $\left.\mathrm{CO}_{2}\right)$ under conditions that resemble landfill conditions. \\
\hline \multirow{3}{*}{$\mathrm{AD}$} & ISO 15985 & $\begin{array}{l}\text { The standard specifies a method for the evaluation of the ultimate anaerobic biodegradability of plastics based on organic compounds under high-solids anaerobic-digestion conditions by measurement } \\
\text { of evolved biogas and the degree of disintegration at the end of the test. }\end{array}$ \\
\hline & ISO 11734 & The standard gives a method for the evaluation of the ultimate biodegradability of organic compounds in digested sludge at a given concentration by anaerobic microorganisms. \\
\hline & ASTM D5210-92 & $\begin{array}{l}\text { This test method determines the degree and rate of anaerobic biodegradation of synthetic plastic materials on exposure to anaerobic-digester municipal sewage sludge from a wastewater treatment } \\
\text { plant, under laboratory conditions. }\end{array}$ \\
\hline $\begin{array}{l}\text { Anaerobic-Aqueous } \\
\text { system }\end{array}$ & ISO 14853 & The method determines the ultimate anaerobic biodegradation of plastic materials in an aqueous system. Biodegradation is measured by biogas production. \\
\hline \multirow{5}{*}{ Marine Environment } & ASTM D6691 & $\begin{array}{l}\text { This test method, conducted under controlled laboratory conditions, is used to determine the degree and rate of aerobic biodegradation of plastic materials exposed to a pre-grown population of at least } \\
\text { ten aerobic marine microorganisms of known genera or the indigenous population existing in natural seawater. }\end{array}$ \\
\hline & ASTM D6692 & $\begin{array}{l}\text { This test method is used to determine the degree of aerobic biodegradation of polymeric compounds utilized in plastic materials by determining the level of respiration of such radiolabeled carbon } \\
\text { compounds to radiolabeled carbon dioxide. } \\
\text { The test is designed to utilize the naturally occurring microbes in seawater as the inoculum for the enrichment and subsequent mineralization (biodegradation) of the test polymer using it as a carbon } \\
\text { and energy source resulting in a carbon dioxide as an end product. }\end{array}$ \\
\hline & ASTM D7473-12 & $\begin{array}{l}\text { This test method is used to determine the weight loss as a function of time of non-floating plastic materials, when incubated under changing, open, marine aquarium conditions, which is representative } \\
\text { of aquatic environments near the coasts and near the bottom of a body of water in the absence of sunlight, particularly UV and visible portions of the spectrum. }\end{array}$ \\
\hline & OECD 306 & $\begin{array}{l}\text { The test gives a first impression of biodegradability in seawater. If the result is positive ( }>70 \% \mathrm{DOC} \text { removal; }>60 \% \mathrm{ThOD}) \text {, it may be concluded that there is a potential for biodegradation in the marine } \\
\text { environment. }\end{array}$ \\
\hline & ISO 16221 & ermine the ultimate aerobic biodegradability of organic compounds in the marine environment by aerobic microorganisms in static aqueous test systems. \\
\hline
\end{tabular}




\section{Concluding Remarks}

This review aimed to evaluate both the efficiency and the rate of biodegradation of bioplastics in different environments. The key findings of this review are:

- Biodegradation under aerobic conditions such as composting, soil, and some aquatic habitats was more rapid compared to that under anaerobic environments, such as anaerobic digestion plants, landfills, and a few aquatic habitats.

- Eighty three percent ( $83 \%$ ) of the experiments cited here were performed in aerobic conditions and over $40 \%$ of them exhibited a biodegradation extent of over $60 \%$ but different times were required. Specifically, from 14 days to 1 year in soil environments, from 28 to 110 days during aerobic composting, and from 14 to 270 days in aquatic environments.

- Only $17 \%$ of the published experiments have taken place under anaerobic conditions and the extent of biodegradation ranged from 2 to $91 \%$; about $50 \%$ of the experiments showed a biodegradability over $70 \%$ in a period from 9 to 75 days; therefore, there is a need to increase the research on the biodegradability of bioplastics in anaerobic conditions.

- The different extent of biodegradation can be attributed to a variety of factors depending on both the nature of the bio-polymers (such as their chemical and physical structure), as well as the environmental conditions to which they are exposed to (such as temperature, moisture, $\mathrm{pH}$, sunlight, nutrient and oxygen availability, and the involved microbial communities).

- Compost was the most investigated environment (accounting for $39 \%$ of the aerobically performed experiments) and that in which almost all biodegradable bioplastics were able to biodegrade.

- The most suitable environment for biodegradation to occur is compost, followed by soil, fresh and marine water, and landfill.

- Almost all the experiments in all environments were conducted at a laboratory scale, thus highlighting the necessity to investigate the biodegradation of bioplastics at real scale, though some of them were carried out in natural environments (for instance, by burying the samples in field soils).

- The majority of the experiments aimed at the optimization of the process by changing the environmental conditions (such as moisture content, temperature, or $\mathrm{pH}$ ) rather than by modifying the physico-chemical structure of the biopolymer (for instance, by pretreatment prior to the biodegradation process); on the other hand, some researchers have tried to enhance the biodegradability of the bioplastics by producing raw materials easier to degrade.

- Only a few biodegradable polymers decompose under all environmental conditions, such as PHA that biodegrades completely in 49 days under composting conditions; on the other hand, its biodegradation in aquatic environments is slower but still complete.

- Cellulose-based bioplastics completely degraded in less than five months in soil and compost conditions, but their degradation has not been investigated under anaerobic and aquatic environments.

- PHA-based bioplastics were degraded (biodegradability over $80 \%$ ) in compost and anaerobic conditions after less than four months and two weeks, respectively; on the contrary, they observed less than $10 \%$ of biodegradability over a period of one year in aquatic environments, while biodegradation was in general below $50 \%$ after one year in soil environment.

- PLA-based bioplastics showed a similar biodegradability of PHAs, as quickly degraded under composting and anaerobic digestion while they were less degraded under the other environments.

- Starch-based bioplastics were degraded in soil and composting, while anaerobic digestion and aquatic environments were not suitable for their degradation.

- Petroleum-based bioplastics (such as PBS and PCL) were degraded by composting $(90 \%$ in three months) but anaerobic, soil, and aquatic environments are not suitable for their degradation. 
- The actual standards assessing the compost quality do not consider particle size smaller than $2 \mathrm{~mm}$, like micro-plastics, thus the introduction of new criteria in ecotoxicity and disintegration tests are highly suggested.

- Anaerobic biodegradation standards for biodegradable bioplastics are lacking and should be developed.

There is a need for wider research in the long-term fate of bioplastics within natural and industrial environments. Even though, environmental conditions may have a significant impact on biodegradation, further studies are required to understand these variables in detail. Thus, further studies can contribute towards the selection of appropriate raw materials that can lead to the minimization of solid wastes, as long as complete mineralization of the biopolymers is achieved. Yet, bioplastics cannot be a panacea to solve the problem of plastic pollution. Even if they can substitute conventional plastics, other plastic management options (prevention, reduction, reuse at the source) must be first considered to minimize plastic pollution.

Author Contributions: Conceptualization, D.K. and P.S.C.; methodology, A.K. and D.K.; investigation, A.K. and A.F.; resources, A.F. and A.K., data curation: A.K.; writing-original draft preparation, A.F., A.K., P.S.C., D.K.; writing-review and editing, D.K., P.S.C.; supervision, D.K. All authors have read and agreed to the published version of the manuscript.

Funding: This research received no external funding.

Conflicts of Interest: The authors declare no conflict of interest.

\begin{tabular}{|c|c|}
\hline $3 \mathrm{HB}$ & 3-hydroxybutyrate \\
\hline $3 \mathrm{HHx}$ & 3-hydroxyhexanoate \\
\hline $3 \mathrm{HV}$ & 3-hydroxyvalerate \\
\hline $\mathrm{AD}$ & Anaerobic Digestion \\
\hline ASTM & American Society for Testing and Materials \\
\hline Bio-PE & Bio-Polyethylene \\
\hline Bio-PET & Bio-Polyethylene Terephthalate \\
\hline Bio-PU & Bio-Polyurethane \\
\hline Bio-PVC & Bio-Polyvinyl Chloride \\
\hline BOD & Biological Oxygen Demand \\
\hline CA & Cellulose Acetate \\
\hline CEN & European Committee for Standardization \\
\hline EOL & End of Life \\
\hline EFB & Empty fruit bunch \\
\hline EPA & Environmental Protection Agency \\
\hline GHG & Greenhouse Gases \\
\hline HRT & Hydraulic Retention Time \\
\hline ISO & International Standards Organization \\
\hline LCA & Life Cycle Assessment (or Analysis) \\
\hline NPK fertilizer & Nitrogen-Phosphorus-Potassium fertilizer \\
\hline OECD & Organization for Economic Cooperation and Development \\
\hline P(3HB-co-3HV-co-3HHx) & Poly(3-hydroxybutyrate-co-3-hydroxyvalerate-co-3-hydroxyhexanoate) \\
\hline PA & Polyamide (or nylon) \\
\hline PBAT & Poly(butylene adipate-co-terephthalate) \\
\hline PBS & Polybutylene Succinate \\
\hline PBSA & Poly(butylene succinate-co-adipate) \\
\hline PCL & Polycaprolactone \\
\hline PGA & Polyglycolide \\
\hline PHA & Polyhydroxyalkanoates \\
\hline PHB & Polyhydroxybutyrate \\
\hline
\end{tabular}




$\begin{array}{ll}\text { PHBV } & \text { Poly(3-hydroxybutyrate-co-3-hydroxyvalerate) } \\ \text { PLA } & \text { Polylactic Acid } \\ \text { PLGA } & \text { Poly(lactic-co-glycolic) Acid } \\ \text { PVA } & \text { Polyvinyl Alcohol } \\ \text { PU } & \text { Polyurethane } \\ \text { SSF } & \text { Solid-State Fermentation } \\ \text { ThOD } & \text { Theoretical Oxygen Demand } \\ \text { TPS } & \text { Thermoplastic Starch } \\ \text { VFA } & \text { Volatile Fatty Acid }\end{array}$

\section{References}

1. Cho, H.S.; Moon, H.S.; Kim, M.; Nam, K.; Kim, J.Y. Biodegradability and biodegradation rate of poly(caprolactone)-starch blend and poly(butylene succinate) biodegradable polymer under aerobic and anaerobic environment. Waste Manag. 2011, 31, 475-480. [CrossRef] [PubMed]

2. Pilla, S. (Ed.) Handbook of Bioplastics and Biocomposites Engineering Applications; John Wiley \& Sons, Inc.: Hoboken, NJ, USA, 2011; ISBN 9781118203699.

3. Tosin, M.; Weber, M.; Siotto, M.; Lott, C.; Degli Innocenti, F.; Briones, A.; Innocenti, F.D. Laboratory test methods to determine the degradation of plastics in marine environmental conditions. Front. Microbiol. 2012, 3, 1-9. [CrossRef] [PubMed]

4. Javierre, C.; Sarasa, J.; Claveria, I.; Fernandez, A. Study of the Biodisintegration on a Painted Bioplastic Material Waste. Mater. Plast. 2015, 52, 116-121.

5. Bilo, F.; Pandini, S.; Sartore, L.; Depero, L.E.; Gargiulo, G.; Bonassi, A.; Federici, S.; Bontempi, E. A sustainable bioplastic obtained from rice straw. J. Clean. Prod. 2018, 200, 357-368. [CrossRef]

6. Koch, D.; Mihalyi, B. Assessing the Change in Environmental Impact Categories when Replacing Conventional Plastic with Bioplastic in Chosen Application Fields. Chem. Eng. Trans. 2018, 70, 853-858.

7. European Bioplastics Report-Bioplastics market data 2019-Global production capacities of bioplastics 2019-2024. Available online: https://www.european-bioplastics.org/market/ (accessed on 21 May 2020).

8. Rhodes, C.J. Solving the plastic problem: From cradle to grave, to reincarnation. Sci. Prog. 2019, 102, $218-248$. [CrossRef]

9. Geyer, R.; Jambeck, J.R.; Law, K.L. Production, use, and fate of all plastics ever made. Sci. Adv. 2017, 3, e1700782. [CrossRef]

10. Sivan, A. New perspectives in plastic biodegradation. Curr. Opin. Biotechnol. 2011, 22, 422-426. [CrossRef]

11. Tachibana, K.; Urano, Y.; Numata, K. Biodegradability of nylon 4 film in a marine environment. Polym. Degrad. Stab. 2013, 98, 1847-1851. [CrossRef]

12. Harmaen, A.S.; Khalina, A.; Azowa, I.; Hassan, M.A.; Tarmian, A.; Jawaid, M. Thermal and biodegradation properties of poly(lactic acid)/fertilizer/oil palm fibers blends biocomposites. Polym. Compos. 2015, 36, 576-583. [CrossRef]

13. Zamakhaeva, S.A.; Fedorov, D.N.; Trotsenko, Y.A. Methylotrophic Producers of Bioplastics (Review). Appl. Biochem. Microbiol. 2017, 53, 389-400. [CrossRef]

14. Jafari-Sales, A. Bioplastics and the Environment. Electron. J. Biol. 2017, 13, 274-279.

15. Sarasa, J.; Gracia, J.M.; Javierre, C. Study of the biodisintegration of a bioplastic material waste. Bioresour. Technol. 2009, 100, 3764-3768. [CrossRef] [PubMed]

16. Calabrò, P.S.; Grosso, M. Bioplastics and waste management. Waste Manag. 2018, 78, 800-801. [CrossRef] [PubMed]

17. Chae, Y.; An, Y.J. Current research trends on plastic pollution and ecological impacts on the soil ecosystem: A review. Environ. Pollut. 2018, 240, 387-395. [CrossRef] [PubMed]

18. Eriksen, M.; Lebreton, L.C.M.; Carson, H.S.; Thiel, M.; Moore, C.J.; Borerro, J.C.; Galgani, F.; Ryan, P.G.; Reisser, J. Plastic Pollution in the World's Oceans: More than 5 Trillion Plastic Pieces Weighing over 250,000 Tons Afloat at Sea. PLoS ONE 2014, 9, e111913. [CrossRef]

19. Harrison, J.P.; Boardman, C.; O'Callaghan, K.; Delort, A.M.; Song, J. Biodegradability standards for carrier bags and plastic films in aquatic environments: A critical review. R. Soc. Open Sci. 2018, 5, 1-18. [CrossRef] 
20. Suzuki, M.; Tachibana, Y.; Oba, K.; Takizawa, R.; Kasuya, K. ichi Microbial degradation of poly( $\varepsilon$-caprolactone) in a coastal environment. Polym. Degrad. Stab. 2018, 149, 1-8. [CrossRef]

21. Xanthos, D.; Walker, T.R. International policies to reduce plastic marine pollution from single-use plastics (plastic bags and microbeads): A review. Mar. Pollut. Bull. 2017, 118, 17-26. [CrossRef]

22. Accinelli, C.; Saccà, M.L.; Mencarelli, M.; Vicari, A. Deterioration of bioplastic carrier bags in the environment and assessment of a new recycling alternative. Chemosphere 2012, 89, 136-143. [CrossRef]

23. Wahyuningtyas, N.; Suryanto, H. Analysis of Biodegradation of Bioplastics Made of Cassava Starch. J. Mech. Eng. Sci. Technol. 2017, 1, 24-31. [CrossRef]

24. Urbanek, A.K.; Rymowicz, W.; Strzelecki, M.C.; Kociuba, W.; Franczak, Ł.; Mirończuk, A.M. Isolation and characterization of Arctic microorganisms decomposing bioplastics. AMB Express 2017, 7, 148. [CrossRef] [PubMed]

25. Luckachan, G.E.; Pillai, C.K.S. Biodegradable Polymers. A Review on Recent Trends and Emerging Perspectives. J. Polym. Environ. 2011, 19, 637-676. [CrossRef]

26. Mohee, R.; Unmar, G.D.; Mudhoo, A.; Khadoo, P. Biodegradability of biodegradable/degradable plastic materials under aerobic and anaerobic conditions. Waste Manag. 2008, 28, 1624-1629. [CrossRef]

27. Prosperi, M.; Sisto, R.; Lombardi, M.; Zhu, X. Production of bioplastics for agricultural purposes: A supply chain study. Riv. di Studi Sulla Sostenibilita 2018, 119-136. [CrossRef]

28. Rujnić-Sokele, M.; Pilipović, A. Challenges and opportunities of biodegradable plastics: A mini review. Waste Manag. Res. 2017, 35, 132-140. [CrossRef]

29. Endres, H.J. Bioplastics. In Biorefineries. Advances in Biochemical Engineering/Biotechnology; Wagemann, K., Tippkötter, N., Eds.; Springer International Publishing: Cham, Switzerland, 2017; Volume 166, pp. 427-468. ISBN 978-3-319-97119-3.

30. Soroudi, A.; Jakubowicz, I. Recycling of bioplastics, their blends and biocomposites: A review. Eur. Polym. J. 2013, 49, 2839-2858. [CrossRef]

31. Ullah, A.; Vasanthan, T.; Bressler, D.; Elias, A.L.; Wu, J. Bioplastics from Feather Quill. Biomacromolecules 2011, 12, 3826-3832. [CrossRef]

32. Wu, C.-S. Preparation, characterization, and biodegradability of renewable resource-based composites from recycled polylactide bioplastic and sisal fibers. J. Appl. Polym. Sci. 2012, 123, 347-355. [CrossRef]

33. Song, J.H.; Murphy, R.J.; Narayan, R.; Davies, G.B.H. Biodegradable and compostable alternatives to conventional plastics. Philos. Trans. R. Soc. B Biol. Sci. 2009, 364, 2127-2139. [CrossRef]

34. Henschen, C. Biplastiche (biosynthetische) Korrekturoperationen von Zehendeformitäten. Schweiz. Med. Wochenschr. 1952, 82, 168-173. [PubMed]

35. Anstey, A.; Muniyasamy, S.; Reddy, M.M.; Misra, M.; Mohanty, A. Processability and Biodegradability Evaluation of Composites from Poly(butylene succinate) (PBS) Bioplastic and Biofuel Co-products from Ontario. J. Polym. Environ. 2014, 22, 209-218. [CrossRef]

36. Kawashima, N.; Yagi, T.; Kojima, K. How Do Bioplastics and Fossil-Based Plastics Play in a Circular Economy? Macromol. Mater. Eng. 2019, 304, 1-14. [CrossRef]

37. Penkhrue, W.; Khanongnuch, C.; Masaki, K.; Pathom-aree, W.; Punyodom, W.; Lumyong, S. Isolation and screening of biopolymer-degrading microorganisms from northern Thailand. World J. Microbiol. Biotechnol. 2015, 31, 1431-1442. [CrossRef] [PubMed]

38. Karamanlioglu, M.; Preziosi, R.; Robson, G.D. Abiotic and biotic environmental degradation of the bioplastic polymer poly(lactic acid): A review. Polym. Degrad. Stab. 2017, 137, 122-130. [CrossRef]

39. Adhikari, D.; Mukai, M.; Kubota, K.; Kai, T.; Kaneko, N.; Araki, K.S.; Kubo, M. Degradation of Bioplastics in Soil and Their Degradation Effects on Environmental Microorganisms. J. Agric. Chem. Environ. 2016, 5, 23-34. [CrossRef]

40. Ryan, C.A.; Billington, S.L.; Criddle, C.S. Assessment of models for anaerobic biodegradation of a model bioplastic: Poly(hydroxybutyrate-co-hydroxyvalerate). Bioresour. Technol. 2017, 227, 205-213. [CrossRef]

41. Mihai, M.; Legros, N.; Alemdar, A. Formulation-properties versatility of wood fiber biocomposites based on polylactide and polylactide/thermoplastic starch blends. Polym. Eng. Sci. 2014, 54, 1325-1340. [CrossRef]

42. Rahman, A.; Syamsu, K. Biodegradability of oil palm cellulose-based bioplastics. IOP Publ. IOP Conf. Ser. Earth Environ. Sci. 2018, 183, 12012.

43. Emadian, S.M.; Onay, T.T.; Demirel, B. Biodegradation of bioplastics in natural environments. Waste Manag. 2017, 59, 526-536. [CrossRef] 
44. Sharma, P.; Gaur, V.K.; Kim, S.H.; Pandey, A. Microbial strategies for bio-transforming food waste into resources. Bioresour. Technol. 2020, 299, 1-11. [CrossRef] [PubMed]

45. Tsang, Y.F.; Kumar, V.; Samadar, P.; Yang, Y.; Lee, J.; Ok, Y.S.; Song, H.; Kim, K.H.; Kwon, E.E.; Jeon, Y.J. Production of bioplastic through food waste valorization. Environ. Int. 2019, 127, 625-644. [CrossRef] [PubMed]

46. Karan, H.; Funk, C.; Grabert, M.; Oey, M.; Hankamer, B. Green Bioplastics as Part of a Circular Bioeconomy. Trends Plant Sci. 2019, 24, 237-249. [CrossRef] [PubMed]

47. Bastos Lima, M.G. Toward multipurpose agriculture: Food, fuels, flex crops, and prospects for a bioeconomy. Glob. Environ. Polit. 2018, 18, 143-150. [CrossRef]

48. Morone, P. The times they are a-changing: Making the transition toward a sustainable economy. Biofuels Bioprod. Biorefining 2016, 10, 369-377. [CrossRef]

49. Kartika, T.; Harahap, M.B.; S Ginting, M.H. Utilization of mango seed starch in manufacture of bioplastic reinforced with microparticle clay using glycerol as plasticizer. IOP Conf. Ser. Mater. Sci. Eng. 2018, 309, 012068.

50. Shellikeri, A.; Kaulgud, V.; Yaradoddi, J.; Ganachari, S.; Banapurmath, N.; Shettar, A. Development of Neem Based Bioplastic for Food Packaging Application. IOP Conf. Ser. Mater. Sci. Eng. 2018, 376, 012052. [CrossRef]

51. Adamcová, D.; Elbl, J.; Zloch, J.; Vaverková, M.D.; Kintl, A.; Juřička, D.; Hladký, J.; Brtnický, M. Study in the (bio)degradation process of bioplastic materials under industrial composting conditions. Acta Univ. Agric. Silvic. Mendelianae Brun. 2017, 65, 791-798.

52. European Bioplastics Bioplastics-European Bioplastics e.V. Available online: https://www.europeanbioplastics.org/bioplastics/ (accessed on 20 January 2020).

53. Ashok, A.; Rejeesh, C.R. Investigations in to Biodegradability and Physical Properties of Starch Derived Bioplastic Films Reinforced with Nanosilica. Int. J. Nanosci. 2019, 18, 1850037. [CrossRef]

54. Gómez, E.F.; Michel, F.C. Biodegradability of conventional and bio-based plastics and natural fiber composites during composting, anaerobic digestion and long-term soil incubation. Polym. Degrad. Stab. 2013, 98, 2583-2591. [CrossRef]

55. Garrison, T.F.; Murawski, A.; Quirino, R.L. Bio-based polymers with potential for biodegradability. Polymers (Basel) 2016, 8, 262. [CrossRef]

56. Arrieta, M.P.; López, J.; Rayón, E.; Jiménez, A. Disintegrability under composting conditions of plasticized PLA-PHB blends. Polym. Degrad. Stab. 2014, 108, 307-318. [CrossRef]

57. Beucker, S.; Marscheider-Weidemann, F. Potentials and Challenges of Bioplastics-Insights from a German Survey on "Green" Future Markets. In Proceedings of the R'07 World Congress; Hilty, L.M., Edelmann, X., Ruf, A., Eds.; EMPA: St. Gallen, Davos, Switzerland, 2007.

58. Plastics Industry Association Plastics Market Watch|Plastics Industry Association. Available online: https: //www.plasticsindustry.org/data/plastics-market-watch (accessed on 2 February 2020).

59. Hong, J.W.; Song, H.S.; Moon, Y.M.; Hong, Y.G.; Bhatia, S.K.; Jung, H.R.; Choi, T.R.; Yang, S.Y.; Park, H.Y.; Choi, Y.K.; et al. Polyhydroxybutyrate production in halophilic marine bacteria Vibrio proteolyticus isolated from the Korean peninsula. Bioprocess Biosyst. Eng. 2019, 42, 603-610. [CrossRef] [PubMed]

60. Bhatia, S.K.; Shim, Y.H.; Jeon, J.M.; Brigham, C.J.; Kim, Y.H.; Kim, H.J.; Seo, H.M.; Lee, J.H.; Kim, J.H.; Yi, D.H.; et al. Starch based polyhydroxybutyrate production in engineered escherichia coli. Bioprocess Biosyst. Eng. 2015, 38, 1479-1484. [CrossRef] [PubMed]

61. Bhatia, S.K.; Gurav, R.; Choi, T.R.; Jung, H.R.; Yang, S.Y.; Song, H.S.; Jeon, J.M.; Kim, J.S.; Lee, Y.K.; Yang, Y.H. Poly(3-hydroxybutyrate-co-3-hydroxyhexanoate) production from engineered Ralstonia eutropha using synthetic and anaerobically digested food waste derived volatile fatty acids. Int. J. Biol. Macromol. 2019, 133, 1-10. [CrossRef] [PubMed]

62. Jung, H.R.; Jeon, J.M.; Yi, D.H.; Song, H.S.; Yang, S.Y.; Choi, T.R.; Bhatia, S.K.; Yoon, J.J.; Kim, Y.G.; Brigham, C.J.; et al. Poly(3-hydroxybutyrate-co-3-hydroxyvalerate-co-3-hydroxyhexanoate) terpolymer production from volatile fatty acids using engineered Ralstonia eutropha. Int. J. Biol. Macromol. 2019, 138, 370-378. [CrossRef]

63. Mostafa, N.A.; Farag, A.A.; Abo-dief, H.M.; Tayeb, A.M. Production of biodegradable plastic from agricultural wastes. Arab. J. Chem. 2018, 11, 546-553. [CrossRef] 
64. Hottle, T.A.; Bilec, M.M.; Landis, A.E. Biopolymer production and end of life comparisons using life cycle assessment. Resour. Conserv. Recycl. 2017, 122, 295-306. [CrossRef]

65. Elvers, D.; Song, C.H.; Steinbüchel, A.; Leker, J. Technology Trends in Biodegradable Polymers: Evidence from Patent Analysis. Polym. Rev. 2016, 56, 584-606. [CrossRef]

66. Mannina, G.; Presti, D.; Montiel-Jarillo, G.; Suárez-Ojeda, M.E. Bioplastic recovery from wastewater: A new protocol for polyhydroxyalkanoates (PHA) extraction from mixed microbial cultures. Bioresour. Technol. 2019, 282, 361-369. [CrossRef]

67. Nwinyi, O.C.; Owolabi, T.A. Scanning electron microscopy and Fourier transmission analysis of polyhydroxyalkanoates isolated from bacteria species from abattoir in Ota, Nigeria. J. King Saud Univ. -Sci. 2019, 31, 285-298. [CrossRef]

68. Ciesielski, S.; Mozejko-Ciesielska, J.; Ciesielski, S. Molecular Identification of Polyhydroxyalkanoates-Producing Bacteria Isolated from Enriched Microbial Community. Pol. J. Microbiol. 2013, 62, 45-50. [CrossRef]

69. Akinmulewo, A.B.; Nwinyi, O.C. Polyhydroxyalkanoate: A biodegradable polymer (a mini review). J. Phys. Conf. Ser. 2019, 1378, 042007. [CrossRef]

70. Bhatia, S.K.; Kim, J.H.; Kim, M.S.; Kim, J.; Hong, J.W.; Hong, Y.G.; Kim, H.J.; Jeon, J.M.; Kim, S.H.; Ahn, J.; et al. Production of (3-hydroxybutyrate-co-3-hydroxyhexanoate) copolymer from coffee waste oil using engineered Ralstonia eutropha. Bioprocess Biosyst. Eng. 2018, 41, 229-235. [CrossRef]

71. Rivero, C.P.; Hu, Y.; Kwan, T.H.; Webb, C.; Theodoropoulos, C.; Daoud, W.; Lin, C.S.K. Bioplastics From Solid Waste. In Current Developments in Biotechnology and Bioengineering: Solid Waste Management; Elsevier Inc.: Amsterdam, The Netherlands, 2017; pp. 1-26. ISBN 9780444636751.

72. Cerda, A.; Artola, A.; Barrena, R.; Font, X.; Gea, T.; Sánchez, A. Innovative Production of Bioproducts From Organic Waste Through Solid-State Fermentation. Front. Sustain. Food Syst. 2019, 3, 1-6. [CrossRef]

73. Vaverková, M.D.; Adamcová, D. Biodegrability of bioplastic materials in a controlled composting environment. J. Ecol. Eng. 2015, 16, 155-160. [CrossRef]

74. Hottle, T.A.; Bilec, M.M.; Landis, A.E. Sustainability assessments of bio-based polymers. Polym. Degrad. Stab. 2013, 98, 1898-1907. [CrossRef]

75. Rincones, J.; Zeidler, A.F.; Grassi, M.C.B.; Carazzolle, M.F.; Pereira, G.A.G. The Golden Bridge for Nature: The New Biology Applied to Bioplastics. Polym. Rev. 2009, 49, 85-106. [CrossRef]

76. Accinelli, C.; Abbas, H.K.; Shier, W.T.; Vicari, A.; Little, N.S.; Aloise, M.R.; Giacomini, S. Degradation of microplastic seed film-coating fragments in soil. Chemosphere 2019, 226, 645-650. [CrossRef]

77. Calabro', P.S.; Folino, A.; Fazzino, F.; Komilis, D. Preliminary evaluation of the anaerobic biodegradability of three biobased materials used for the production of disposable plastics. J. Hazard. Mater. 2020, 390, 121653. [CrossRef]

78. Vink, E.T.H.; Rábago, K.R.; Glassner, D.A.; Springs, B.; O'Connor, R.P.; Kolstad, J.; Gruber, P.R. The Sustainability of NatureWorks ${ }^{\mathrm{TM}}$ Polylactide Polymers and Ingeo ${ }^{\mathrm{TM}}$ Polylactide Fibers: An Update of the Future. Macromol. Biosci. 2004, 4, 551-564. [CrossRef] [PubMed]

79. Patel, S.K.S.; Sandeep, K.; Singh, M.; Singh, G.P.; Lee, J.K.; Bhatia, S.K.; Kalia, V.C. Biotechnological application of polyhydroxyalkanoates and their composites as anti-microbials agents. In Biotechnological Applications of Polyhydroxyalkanoates; Springer: Singapore, 2019; pp. 207-225. ISBN 9789811337598.

80. Bhatia, S.K.; Wadhwa, P.; Bhatia, R.K.; Patel, S.K.S.; Yang, Y.H. Strategy for biosynthesis of polyhydroxyalkonates polymers/copolymers and their application in drug delivery. In Biotechnological Applications of Polyhydroxyalkanoates; Springer: Singapore, 2019; pp. 13-34. ISBN 9789811337598.

81. Bhatia, S.K.; Wadhwa, P.; Hong, J.W.; Hong, Y.G.; Jeon, J.M.; Lee, E.S.; Yang, Y.H. Lipase mediated functionalization of poly(3-hydroxybutyrate-co-3-hydroxyvalerate) with ascorbic acid into an antioxidant active biomaterial. Int. J. Biol. Macromol. 2019, 123, 117-123. [CrossRef] [PubMed]

82. Vu, D.H.; Åkesson, D.; Taherzadeh, M.J.; Ferreira, J.A. Recycling strategies for polyhydroxyalkanoate-based waste materials: An overview. Bioresour. Technol. 2020, 298, 1-9. [CrossRef]

83. Jamshidian, M.; Tehrany, E.A.; Imran, M.; Jacquot, M.; Desobry, S. Poly-Lactic Acid: Production, applications, nanocomposites, and release studies. Compr. Rev. Food Sci. Food Saf. 2010, 9, 552-571. [CrossRef]

84. Albuquerque, P.B.S.; Malafaia, C.B. Perspectives on the production, structural characteristics and potential applications of bioplastics derived from polyhydroxyalkanoates. Int. J. Biol. Macromol. 2018, 107, 615-625. [CrossRef] [PubMed] 
85. Ciriminna, R.; Pagliaro, M. Biodegradable and Compostable Plastics: A Critical Perspective on the Dawn of their Global Adoption. ChemistryOpen 2020, 9, 8-13. [CrossRef] [PubMed]

86. Saiful; Helwati, H.; Saleha, S.; Iqbalsyah, T.M. Development of bioplastic from wheat Janeng starch for food packaging. In Proceedings of the The 8th Annual International Conference (AIC) 2018 on Science and Engineering, Aceh, Indonesia, 12-14 September 2018.

87. Saxena, A.; Tiwari, A. Polyhydroxyalkonates: Green plastics of the future. Int. J. Biomed. Adv. Res. 2011, 2, 356-367. [CrossRef]

88. Gironi, F.; Piemonte, V. Bioplastics and petroleum-based plastics: Strengths and weaknesses. Energy Sources, Part A Recover. Util. Environ. Eff. 2011, 33, 1949-1959. [CrossRef]

89. Kourmentza, C.; Plácido, J.; Venetsaneas, N.; Burniol-Figols, A.; Varrone, C.; Gavala, H.N.; Reis, M.A.M. Recent Advances and Challenges towards Sustainable Polyhydroxyalkanoate (PHA) Production. Bioengineering 2017, 4, 55. [CrossRef]

90. Leong, Y.K.; Show, P.L.; Lan, J.C.W.; Loh, H.S.; Lam, H.L.; Ling, T.C. Economic and environmental analysis of PHAs production process. Clean Technol. Environ. Policy 2017, 19, 1941-1953. [CrossRef]

91. Jain, R.; Tiwari, A. Biosynthesis of planet friendly bioplastics using renewable carbon source. J. Environ. Heal. Sci. Eng. 2015, 13, 11. [CrossRef] [PubMed]

92. Gu, J.-D.; Eberiel, D.T.; Mccarthy, S.P.; Gross, R.A. Cellulose Acetate Biodegradability upon Exposure to Simulated Aerobic Composting and Anaerobic Bioreactor Environments 1. J. Environ. Polym. Degrad. 1993, 1, 143-153. [CrossRef]

93. Peelman, N.; Ragaert, P.; De Meulenaer, B.; Adons, D.; Peeters, R.; Cardon, L.; Van Impe, F.; Devlieghere, F. Application of bioplastics for food packaging. Trends Food Sci. Technol. 2013, 32, 128-141. [CrossRef]

94. Wei, L.; McDonald, A.G. Accelerated weathering studies on the bioplastic, poly(3-hydroxybutyrate-co-3-hydroxyvalerate). Polym. Degrad. Stab. 2016, 126, 93-100. [CrossRef]

95. Ochi, S. Development of high strength biodegradable composites using Manila hemp fiber and starch-based biodegradable resin. Compos. Part A Appl. Sci. Manuf. 2006, 37, 1879-1883. [CrossRef]

96. Stevens, E.S.; Klamczynski, A.; Glenn, G.M. Starch-lignin foams. Express Polym. Lett. 2010, 4, 311-320. [CrossRef]

97. Yang, J.; Ching, Y.C.; Chuah, C.H. Applications of Lignocellulosic Fibers and Lignin in Bioplastics: A Review. Polymers (Basel) 2019, 11, 751. [CrossRef]

98. Ching, K.Y.; Chee, C.Y.; Afzan, M.; Kang, L.Z.; Eng, C.K. Mechanical and thermal properties of Chemical treated oil palm empty fruit bunches fiber reinforced polyvinyl alcohol composite. J. Biobased Mater. Bioenergy 2015, 9, 231-235. [CrossRef]

99. Ali, M.E.; Yong, C.K.; Ching, Y.C.; Chuah, C.H.; Liou, N.S. Effect of single and double stage chemically treated kenaf fibers on mechanical properties of polyvinyl alcohol film. BioResources 2015, 10, 822-838. [CrossRef]

100. Yong, C.K.; Ching, Y.C.; Chuah, C.H.; Liou, N.S. Effect of fiber orientation on mechanical properties of kenaf-reinforced polymer composite. BioResources 2015, 10, 2597-2608. [CrossRef]

101. Muhammad, A.; Roslan, A.; Sanusi, S.N.A.; Shahimi, M.Q.; Nazari, N.Z. Mechanical properties of bioplastic form cellulose nanocrystal (CNC) mangosteen peel using glycerol as plasticizer. J. Phys. Conf. Ser. 2019, 1349, 012099. [CrossRef]

102. Jangong, O.S.; Gareso, P.L.; Mutmainna, I.; Tahir, D. Fabrication and characterization starch/chitosan reinforced polypropylene as biodegradable. J. Phys. Conf. Ser. 2019, 1341, 082022. [CrossRef]

103. Sun, Y.; Yang, L.; Lu, X.; He, C. Biodegradable and renewable poly(lactide)-lignin composites: Synthesis, interface and toughening mechanism. J. Mater. Chem. A 2015, 3, 3699-3709. [CrossRef]

104. Suryanto, H.; Kharismawan, F.A.; Solichin; Rahmawan, A.W.; Sahana, R.T.; Muhajir, M.; Yanuhar, U. Influence of Nanoclay on Thermal Decomposition of Biocomposite Matrix Starch/Carrageenan Blend. IOP Conf. Ser. Mater. Sci. Eng. 2019, 494, 012077. [CrossRef]

105. Jafar, A.; Mostafa, R.-T.; Esmaeil, B.; Heidari, K.S.; Rahim, J. Mechanical properties of chitosan-starch composite filled hydroxyapatite micro-and nanopowders. J. Nanomater. 2011, 2011, 1-16.

106. Masruri, M.; Azhar, A.Z.; Rosyada, I.; Febrianto, A. The effect of kaffir lime (Citrus hystrix DC) essential oil on bioplastic derived from cassava peel waste. J. Phys. Conf. Ser. 2019, 1374, 012015. [CrossRef]

107. Abdullah, A.H.D.; Fikriyyah, A.K.; Putri, O.D.; Puspa Asri, P.P. Fabrication and Characterization of Poly Lactic Acid (PLA)-Starch Based Bioplastic Composites. IOP Conf. Ser. Mater. Sci. Eng. 2019, 553, 012052. [CrossRef] 
108. Jiménez-Rosado, M.; Zarate-Ramírez, L.S.; Romero, A.; Bengoechea, C.; Partal, P.; Guerrero, A. Bioplastics based on wheat gluten processed by extrusion. J. Clean. Prod. 2019, 239. [CrossRef]

109. Maulida, M.; Siagian, P. Tarigan Production of Starch Based Bioplastic from Cassava Peel Reinforced with Microcrystalline Celllulose Avicel PH101 Using Sorbitol as Plasticizer Related content. J. Phys. Conf. Ser. 2016, 710, 1-8. [CrossRef]

110. Niaounakis, M. Recycling of biopolymers-The patent perspective. Eur. Polym. J. 2019, 114, 464-475. [CrossRef]

111. Massardier-Nageotte, V.; Pestre, C.; Cruard-Pradet, T.; Bayard, R. Aerobic and anaerobic biodegradability of polymer films and physico-chemical characterization. Polym. Degrad. Stab. 2006, 91, 620-627. [CrossRef]

112. Nakasaki, K.; Matsuura, H.; Tanaka, H.; Sakai, T. Synergy of two thermophiles enables decomposition of poly-e-caprolactone under composting conditions. Fed. Eur. Microbiol. Soc. 2006, 58, 373-383. [CrossRef] [PubMed]

113. Ryan, C.A.; Billington, S.L.; Criddle, C.S. Biocomposite Fiber-Matrix Treatments that Enhance In-Service Performance Can Also Accelerate End-of-Life Fragmentation and Anaerobic Biodegradation to Methane. J. Polym. Environ. 2018, 26, 1715-1726. [CrossRef]

114. Menicagli, V.; Balestri, E.; Lardicci, C. Exposure of coastal dune vegetation to plastic bag leachates: A neglected impact of plastic litter. Sci. Total Environ. 2019, 683, 737-748. [CrossRef] [PubMed]

115. Li, M.; Witt, T.; Xie, F.; Warren, F.J.; Halley, P.J.; Gilbert, R.G. Biodegradation of starch films: The roles of molecular and crystalline structure. Carbohydr. Polym. 2015, 122, 115-122. [CrossRef]

116. Bátori, V.; Åkesson, D.; Zamani, A.; Taherzadeh, M.J.; Sárvári Horváth, I. Anaerobic degradation of bioplastics: A review. Waste Manag. 2018, 80, 406-413. [CrossRef]

117. Arcos-Hernandez, M.V.; Laycock, B.; Pratt, S.; Donose, B.C.; Nikolič, M.A.L.; Luckman, P.; Werker, A.; Lant, P.A. Biodegradation in a soil environment of activated sludge derived polyhydroxyalkanoate (PHBV). Polym. Degrad. Stab. 2012, 97, 2301-2312. [CrossRef]

118. Thakur, S.; Chaudhary, J.; Sharma, B.; Verma, A.; Tamulevicius, S.; Thakur, V.K. Sustainability of bioplastics: Opportunities and challenges. Curr. Opin. Green Sustain. Chem. 2018, 13, 68-75. [CrossRef]

119. Evangelou, A.; Calabrò, P.S.; Greco, R.; Sánchez, A.; Komilis, D. Biodegradation Activity of Eight Organic Substrates: A Correlation Study of Different Test Methods. Waste Biomass Valorization 2016, 7, 1067-1080. [CrossRef]

120. Nishide, H.; Toyota, K.; Kimura, M. Effects of soil temperature and anaerobiosis on degradation of biodegradable plastics in soil and their degrading microorganisms. Soil Sci. Plant Nutr. 1999, 45, 963-972. [CrossRef]

121. Volova, T.G.; Gladyshev, M.I.; Trusova, M.Y.; Zhila, N.O. Degradation of polyhydroxyalkanoates in eutrophic reservoir. Polym. Degrad. Stab. 2007, 92, 580-586. [CrossRef]

122. Yagi, H.; Ninomiya, F.; Funabashi, M.; Kunioka, M. Bioplastic biodegradation activity of anaerobic sludge prepared by preincubation at $55^{\circ} \mathrm{C}$ for new anaerobic biodegradation test. Polym. Degrad. Stab. 2010, 95, 1349-1355.

123. Boyandin, A.N.; Prudnikova, S.V.; Karpov, V.A.; Ivonin, V.N.; Dỗ, N.L.; Nguyễn, T.H.; Lê, T.M.H.; Filichev, N.L.; Levin, A.L.; Filipenko, M.L.; et al. Microbial degradation of polyhydroxyalkanoates in tropical soils. Int. Biodeterior. Biodegrad. 2013, 83, 77-84. [CrossRef]

124. Wu, C.S. Preparation and Characterization of Polyhydroxyalkanoate Bioplastic-Based Green Renewable Composites from Rice Husk. J. Polym. Environ. 2014, 22, 384-392. [CrossRef]

125. Haig, S.; Morrish, L.; Morton, R.; Wilkinson, S. Film Reprocessing Technologies and Collection Schemes; WRAP (Waste \& Resources Action Programme): Banbury, UK, 2018.

126. Degli-Innocenti, F. Biodegradation of plastics and ecotoxicity testing: When should it be done. Front. Microbiol. 2014, 5, 1-3. [CrossRef] [PubMed]

127. Ruggero, F.; Gori, R.; Lubello, C. Methodologies to assess biodegradation of bioplastics during aerobic composting and anaerobic digestion: A review. Waste Manag. Res. 2019, 37, 959-975. [CrossRef]

128. Woolnough, C.A.; Charlton, T.; Yee, L.H.; Sarris, M.; Foster, L.J.R. Surface changes in polyhydroxyalkanoate films during biodegradation and biofouling. Polym. Int. 2008, 57, 1042-1051. [CrossRef]

129. Balaguer, M.P.; Aliaga, C.; Fito, C.; Hortal, M. Compostability assessment of nano-reinforced poly(lactic acid) films. Waste Manag. 2016, 48, 143-155. [CrossRef]

130. Balaguer, M.P.; Villanova, J.; Cesar, G.; Gavara, R.; Hernandez-Munoz, P. Compostable properties of antimicrobial bioplastics based on cinnamaldehyde cross-linked gliadins. Chem. Eng. J. 2015, 262, 447-455. [CrossRef] 
131. Tchobanoglous, G.; Theisen, H.; Vigil, S.A. Integrated Solid Waste Management: Engineering Principles And Management Issues; McGraw-Hill Education: New York, NY, USA, 1993; ISBN 0070632375.

132. Bhatt, R.; Shah, D.; Patel, K.C.; Trivedi, U. PHA-rubber blends: Synthesis, characterization and biodegradation. Bioresour. Technol. 2008, 99, 4615-4620. [CrossRef] [PubMed]

133. Hashimoto, K.; Sudo, M.; Ohta, K.; Sugimura, T.; Yamada, H.; Aoki, T. Biodegradation of nylon4 and its blend with nylon6. J. Appl. Polym. Sci. 2002, 86, 2307-2311. [CrossRef]

134. Volova, T.G.; Boyandin, A.N.; Vasiliev, A.D.; Karpov, V.A.; Prudnikova, S.V.; Mishukova, O.V.; Boyarskikh, U.A.; Filipenko, M.L.; Rudnev, V.P.; Bá Xuân, B.; et al. Biodegradation of polyhydroxyalkanoates (PHAs) in tropical coastal waters and identification of PHA-degrading bacteria. Polym. Degrad. Stab. 2010, 95, 2350-2359. [CrossRef]

135. Butbunchu, N.; Pathom-Aree, W. Actinobacteria as Promising Candidate for Polylactic Acid Type Bioplastic Degradation. Front. Microbiol. 2019, 10, 1-10. [CrossRef] [PubMed]

136. Roohi; Zaheer, M.R.; Kuddus, M. PHB (poly- $\beta$-hydroxybutyrate) and its enzymatic degradation. Polym. Adv. Technol. 2018, 29, 30-40. [CrossRef]

137. Ignatyev, I.A.; Thielemans, W.; Vander Beke, B. Recycling of polymers: A review. ChemSusChem 2014, 7, 1579-1593. [CrossRef]

138. Singh, N.; Hui, D.; Singh, R.; Ahuja, I.P.S.; Feo, L.; Fraternali, F. Recycling of plastic solid waste: A state of art review and future applications. Compos. Part B Eng. 2017, 115, 409-422. [CrossRef]

139. Scott, G. 'Green' polymers. Polym. Degrad. Stab. 2000, 68, 1-7. [CrossRef]

140. Fábio Rivas, L.; Aline Casarin, S.; Cavalcante Nepomuceno, N.; Isabele Alencar, M.; Augusto Marcondes Agnelli, J.; Souto de Medeiros, E.; de Oliveira Wanderley Neto, A.; Pinheiro de Oliveira, M.; Marcos de Medeiros, A.; Severino Ferreira Santos, A. Reprocessability of PHB in extrusion: ATR-FTIR, tensile tests and thermal studies. Polímeros 2017, 27, 122-128. [CrossRef]

141. Ariffin, H.; Nishida, H.; Hassan, M.A.; Shirai, Y. Chemical recycling of polyhydroxyalkanoates as a method towards sustainable development. Biotechnol. J. 2010, 5, 484-492. [CrossRef]

142. Voinova, O.N.; Kozhevnikova, N.A.; Gladyshev, M.I.; Volova, T.G. Bioplastic degradation in natural reservoirs differing in ecological parameters. Dokl. Biol. Sci. 2007, 417, 426-428. [CrossRef]

143. Shruti, V.C.; Kutralam-Muniasamy, G. Bioplastics: Missing link in the era of Microplastics. Sci. Total Environ. 2019, 697, 1-14. [CrossRef]

144. Wierckx, N.; Narancic, T.; Eberlein, C.; Wei, R.; Drzyzga, O.; Magnin, A.; Ballerstedt, H.; Kenny, S.T.; Pollet, E.; Avérous, L.; et al. Plastic Biodegradation: Challenges and Opportunities. In Consequences of Microbial Interactions with Hydrocarbons, Oils, and Lipids: Biodegradation and Bioremediation; Springer International Publishing: Cham, Switzerland, 2018.

145. Siracusa, V. Microbial Degradation of Synthetic Biopolymers Waste. Polymers (Basel) 2019, 11, 1066. [CrossRef]

146. Elsawy, M.A.; Kim, K.H.; Park, J.W.; Deep, A. Hydrolytic degradation of polylactic acid (PLA) and its composites. Renew. Sustain. Energy Rev. 2017, 79, 1346-1352. [CrossRef]

147. Müller, R. Biodegradation behaviour of polymers in liquid environments. In Handbook of Biodegradable Polymers; Walter de Gruyter GmbH: Berlin, Gemany, 2006.

148. Hablot, E.; Dharmalingam, S.; Hayes, D.G.; Wadsworth, L.C.; Blazy, C.; Narayan, R.; Hablot, E.; Blazy, Á.C.; Narayan, Á.R.; Dharmalingam, S.; et al. Effect of Simulated Weathering on Physicochemical Properties and Inherent Biodegradation of PLA/PHA Nonwoven Mulches. J. Polym. Environ. 2014, 22, 417-429. [CrossRef]

149. Mutmainna, I.; Tahir, D.; Lobo Gareso, P.; Ilyas, S. Synthesis composite starch-chitosan as biodegradable plastic for food packaging. J. Phys. Conf. Ser. 2019, 1317, 012053. [CrossRef]

150. Nissa, R.C.; Fikriyyah, A.K.; Abdullah, A.H.D.; Pudjiraharti, S. Preliminary study of biodegradability of starch-based bioplastics using ASTM G21-70, dip-hanging, and Soil Burial Test methods. IOP Conf. Ser. Earth Environ. Sci. 2019, 277, 012007. [CrossRef]

151. Martins-Franchetti, S.M.; De Campos, A.; Marconato, J.C. The Influence of Soil and Landfill Leachate Microorganisms in the Degradation of PVC/PCL Films Cast from DMF. Polimeros 2012, 22, 220-227.

152. Wu, C.S. A comparison of the structure, thermal properties, and biodegradability of polycaprolactone/chitosan and acrylic acid grafted polycaprolactone/chitosan. Polymer (Guildf) 2005, 46, 147-155. [CrossRef]

153. Di Franco, C.R.; Cyras, V.P.; Busalmen, J.P.; Ruseckaite, R.A.; Vázquez, A. Degradation of polycaprolactone/starch blends and composites with sisal fibre. Polym. Degrad. Stab. 2004, 86, 95-103. [CrossRef] 
154. Innocenti, F.D.; Razza, F.; Fieschi, M.; Bastioli, C.; Fieschi, S.; Donizetti, V.G. Life Cycle Management in bioplastics production. In Proceedings of the 3rd International Conference on Life cycle management, Zurich, Switzerland, 27-29 August 2007.

155. Kale, G.; Auras, R.; Singh, S.P.; Narayan, R. Biodegradability of polylactide bottles in real and simulated composting conditions. Polym. Test. 2007, 26, 1049-1061. [CrossRef]

156. Lavagnolo, M.C.; Ruggero, F.; Chiumenti, A. Fate of bioplastics in composting. In Proceedings of the 16th International Waste Management and Landfill Symposium Santa Margherita di Pula, Sardinia, Italy, 2-6 October 2017.

157. Weng, Y.X.; Wang, X.L.; Wang, Y.Z. Biodegradation behavior of PHAs with different chemical structures under controlled composting conditions. Polym. Test. 2011, 30, 372-380. [CrossRef]

158. Tabasi, R.Y.; Ajji, A. Selective degradation of biodegradable blends in simulated laboratory composting. Polym. Degrad. Stab. 2015, 120, 435-442. [CrossRef]

159. Ahn, H.K.; Huda, M.S.; Smith, M.C.; Mulbry, W.; Schmidt, W.F.; Reeves, J.B. Biodegradability of injection molded bioplastic pots containing polylactic acid and poultry feather fiber. Bioresour. Technol. 2011, 102, 4930-4933. [CrossRef] [PubMed]

160. Hegde, S.; Dell, E.; Lewis, C.; Trabold, T.A.; Diaz, C.A. Anaerobic biodegradation of bioplastic packaging materials. In Proceedings of the 21st IAPRI World Conference on Packaging 2018-Packaging: Driving a Sustainable Future, Zhuhai, China, 19-22 June 2018; DEStech Publications Inc.: Lancaster, PA, USA, 2019; pp. 730-737.

161. Yagi, H.; Ninomiya, F.; Funabashi, M.; Kunioka, M. Mesophilic anaerobic biodegradation test and analysis of eubacteria and archaea involved in anaerobic biodegradation of four specified biodegradable polyesters. Polym. Degrad. Stab. 2014, 110, 278-283. [CrossRef]

162. Zhang, W.; Heaven, S.; Banks, C.J. Degradation of some EN13432 compliant plastics in simulated mesophilic anaerobic digestion of food waste. Polym. Degrad. Stab. 2018, 147, 76-88. [CrossRef]

163. Yagi, H.; Ninomiya, F; Funabashi, M.; Kunioka, M. Thermophilic anaerobic biodegradation test and analysis of eubacteria involved in anaerobic biodegradation of four specified biodegradable polyesters. Polym. Degrad. Stab. 2013, 98, 1182-1187. [CrossRef]

164. Benn, N.; Zitomer, D. Pretreatment and Anaerobic Co-digestion of Selected PHB and PLA Bioplastics. Front. Environ. Sci. 2018, 5, 93. [CrossRef]

165. Yu, J. Production of Biodegradable Thermoplastic Materials from Organic Wastes 1-6. U.S. Patent No 7,141,400, 28 November 2006.

166. Abou-Zeid, D.M.; Müller, R.J.; Deckwer, W.D. Degradation of natural and synthetic polyesters under anaerobic conditions. J. Biotechnol. 2001, 86, 113-126. [CrossRef]

167. Yagi, H.; Ninomiya, F.; Funabashi, M.; Kunioka, M. Anaerobic biodegradation tests of poly(lactic acid) under mesophilic and thermophilic conditions using a new evaluation system for methane fermentation in anaerobic sludge. Int. J. Mol. Sci. 2009, 10, 3824-3835. [CrossRef]

168. Bagheri, A.R.; Laforsch, C.; Greiner, A.; Agarwal, S. Fate of So-Called Biodegradable Polymers in Seawater and Freshwater. Glob. Chall. 2017, 1, 1700048. [CrossRef]

169. California State University; Greene, J. Mechatronic Engineering and Manifacturing Technology. In PLA and PHA Biodegradation in the Marine Environment; CalRecycle: Sacramento, CA, USA, 2012.

170. Sridewi, N.; Bhubalan, K.; Sudesh, K. Degradation of commercially important polyhydroxyalkanoates in tropical mangrove ecosystem. Polym. Degrad. Stab. 2006, 91, 2931-2940. [CrossRef]

171. Thellen, C.; Coyne, M.; Froio, D.; Auerbach, M.; Wirsen, C.; Ratto, J.A. A processing, characterization and marine biodegradation study of melt-extruded polyhydroxyalkanoate (PHA) films. J. Polym. Environ. 2008, 16, 1-11. [CrossRef]

172. Bioplastics Guide Bioplastics Standards \& Certifications-ASTM, ISO, CEN, DIN Certco, Vincotte-Bioplastics Guide|Bioplastics Guide. Available online: http://www.bioplastics.guide/ref/bioplastics/standards-andcertifications/ (accessed on 2 February 2020).

173. OECD Test No. 208 Terrestrial Plant Test: Seedling Emergence and Seedling Growth Test. In OECD Guidelines for the Testing of Chemicals, Section 2; OECD Publishing: Paris, France, 2006; pp. 1-21. ISBN 9789264070066.

(C) 2020 by the authors. Licensee MDPI, Basel, Switzerland. This article is an open access article distributed under the terms and conditions of the Creative Commons Attribution (CC BY) license (http://creativecommons.org/licenses/by/4.0/). 